\title{
Historie a perspektivy sportovního muzejnictví v ČR na príkladu Oddělení dějin tělesné výchovy a sportu Národního muzea ${ }^{1}$
}

1 Předložená práce vznikla za finanční podpory Ministerstva kultury $v$ rámci institucionálního financování dlouhodobého koncepčniho rozvoje výzkumné organizace Národní muzeum (DKRVO 2019-2023/10.IV.a, 00023272)

Mgr. Jan Lomíček Ph.D. Oddělení dějin tělesné výchovy a sportu Národní muzeum jan.lomicek@nm.cz

\section{History and Perspectives of the Czech Sports Museology on the Example of the Department of the History of Physical Education and Sport of the National Museum}

Abstract: The Department of Physical Education and Sports History of The National Museum administrates the oldest museum collection of exhibits and materials in the Czech Republic focusing on sports, physical education and olympism history not only in Czech lands, but also abroad. The crucial and considerable problem is the absence of a permanent exhibition, which would facilitate a systematic and permanent communication not only with non-professional public, but also with sport and museum professionals. This is a common practice abroad where various sport and olympic museums are an integral part of national cultural heritage. There has not been a permanent exhibition of Czech sport for twenty years and thus various local and private museums substitute its non-existence. Presentation of sport, physical education and olympic historic collection of the National Museum is thus doubtful. The situation in other countries in Central Europe is completely different. This paper deals with the history of The Department of Physical Education and Sports History collection, summarizes the situation in the Czech Republic and in other countries of the Visegrad group. At the end, the paper offers possible approaches that could be adopted in future practice.

Keywords: history of sports, history of Physical Education, Olympism, museum of sport, Sokol movement, Olympic museums, The Department of Physical Education and Sports History

Oddělení dějin tělesné výchovy a sportu (ODTVS) Národního muzea a Archiv tělesné výchovy a sportu, spadající pod Archiv Národního muzea, představují nejstarší kontinuálně fungující a rozšiřované sbírky v ČR věnované soustavnému mapování dějin sportu, tělesné výchovy a českého i československého olympismu. Výrazným problémem, který se ukazuje v mnoha směrech jako limitující, je absence trvalé expozice, která by umožňovala soustavnou komunikaci s laickou i odbornou veřejností v oblasti expoziční, akviziční i výzkumné. $\mathrm{V}$ zahraničí se muzea věnovaná historii různých aspektů sportu a tělesné výchovy v průběhu uplynulého století etablovala mnohdy jako nedílná součást kulturního dědictví. $V$ prrípadě ODTVS je trend spíše opačný. Po opuštění původních výstavních prostor $\mathrm{v}$ Tyršově domě na pražském Újezdě, ke kterému došlo po povodních $\mathrm{v}$ roce 2002, zůstává situace $\mathrm{z}$ pohledu prezentace bohatých sportovních sbírek i po dvou desetiletích neměnná. Funkci stálé expozice začínají postupně suplovat lokální muzea a soukromé výstavní síně. V zahraničí je situace $\mathrm{v}$ podstatě ve všech zemích střední Evropy značně odlišná. Text shrnuje stručný vývoj současné sbírky Oddělení dějin tělesné výchovy a sportu Národního 
muzea, následně se stručně zaměřuje na situaci na území ČR a v zemích visegrádské čtyřky, které měly po společenských změnách na prahu devadesátých let obdobné podmínky. $\mathrm{V}$ závěru rozebírá možné perspektivy, které se v oblasti muzejní prezentace témat spojených $\mathrm{s}$ historií tělesné výchovy, sportu a olympismu nabízejí.

\section{Nástin historie sportovní a tèlovýchovné muzeologie $v$ českých zemích}

Sbírky Oddělení dějin tělesné výchovy a sportu Historického muzea NM odvíjejí svou historii od sokolských muzeí, $\mathrm{z}$ nichž první se formovalo již $\mathrm{v}$ průběhu 19. století, druhé pak v meziválečném období ve století dvacátém. Nejstarším muzeem na našem území, které se zaměřilo na dějiny sokolského hnutí a tělovýchovy, bylo Muzeum Sokola Pražského. Počátky jeho sbírek se datují do roku 1864, kdy byla v rámci první pražské sokolovny na popud jednoho ze zakladatelů Sokola Jindřicha Fügnera vyčleněna místnost pro uchovávání sokolských memorabilií. Podnět ke vzniku vlastního Muzea Sokola Pražského v roce 1885 dala až výstava uspořádaná po smrti další zakládající osobnosti sokolského hnutí, dr. Miroslava Tyrše. Ve stejném období byl založen i všesokolský archiv, který měl uchovávat dokumenty listinné povahy. Prvním sídlem obou institucí se stala sokolovna Sokola Pražského. ${ }^{2}$ Sbírka Muzea Sokola Pražského byla významně obohacena po smrti vdovy po Miroslavu Tyršovi (a dcery Jindřicha Fügnera) Renáty Tyršové v roce 1937. V návaznosti bylo Muzeum Sokola Pražského v budově první sokolské tělocvičny transformováno do Muzea dr. Miroslava Tyrše a Jindřicha Fügnera. Do činnosti muzea následně zasáhla německá okupace, $\mathrm{v}$ roce 1941 byla sokolská organizace rozpuštěna a její majetek byl zkonfiskován. Sbírky byly odvezeny, rozděleny a ukryty mezi členy jednoty, část z nich se však uchránit nepodařilo. Po osvobození v roce 1945 byla většina sbírek svezena zpět. Př̀i předání sbírek proběhla také jejich první katalogizace. ${ }^{3}$
Druhým sokolským muzeem, jehož fond se stal základem sbírky mapující dějiny tělesné výchovy a sportu v NM, bylo Sokolské muzeum (Muzeum ČOS). Jeho prazákladem byly výstavy věnované sokolskému hnutí, které byly uspořádány během velkých výstavních akcí $\mathrm{v}$ rámci Všeobecné jubilejní zemské výstavy $\mathrm{v}$ roce 1891 a zejména během Národopisné výstavy českoslovanské v roce 1895, kde měli sokolové svůj vlastní pavilón uspořádaný $\mathrm{v}$ duchu vzorné sokolské tělocvičny. Vedle dalších sokolských memorabilií byly obě dílčí expozice věnovány i působení českých sokolů v zahraničí a zahraničním sokolským organizacím. Právě v souvislosti s expozicí v rámci Národopisné výstavy českoslovanské začala $\mathrm{v}$ sokolské obci více rezonovat myšlenka na zř́zení Sokolského muzea. Sokolské výstavy byly pořádány i během následujících sokolských sletů $v$ roce 1901 během IV. všesokolského sletu v Praze a v roce 1912 během VI. všesokolského sletu (či Sletu slovanského sokolstva, jak byl také označován). Po poslední zmíněné akci byla myšlenka sokolského muzea oživena a těsně před vypuknutím první světové války podala ČOS smíchovské městské radě žádost o propůjčení prostor k umístění sokolských sbírek. Rada propůjčila ČOS místnosti v obecní vile na Santošce č. p. 178, kam byly sbírky sokolských memorabilií odvezeny a následně odevzdány nově vzniklé Společnosti muzea tělocvičného, a to bezprostředně před úředním rozpuštěním České obce sokolské v roce 1915. Muzeum bylo otevřeno po skončení světové války v roce $1920 .{ }^{4}$

V souvislosti s řešením nového sídla pro jednotlivé součásti České obce sokolské byl v roce 1921 zakoupen Michnův palác budoucí Tyršův dům, kam byly po rekonstrukci v roce 1924 sokolské muzejní sbírky přesunuty. Dne 24. května 1924 pak byl Tyršův dům slavnostně otevřen za účasti prezidenta republiky. $\mathrm{V}$ meziválečném období byla do sbírek začleněna i umělecká sbírka, kterou ČOS věnoval básník a spisovatel Jiří Karásek ze Lvovic. V padesátých letech však byla převedena do správy Památníku národního písemnictví.
2 ŠTURSOVÁ, Květoslava. Tyršovo muzeum tělesné výchovy a sportu 1953-2003. Praha: Národní muzeum, 2003, s. 9. Současná adresa sokolovny je Sokolská 43, Praha 2. 3 Ibidem, s. 10-12.

4 Ibidem, s. 13-15. 


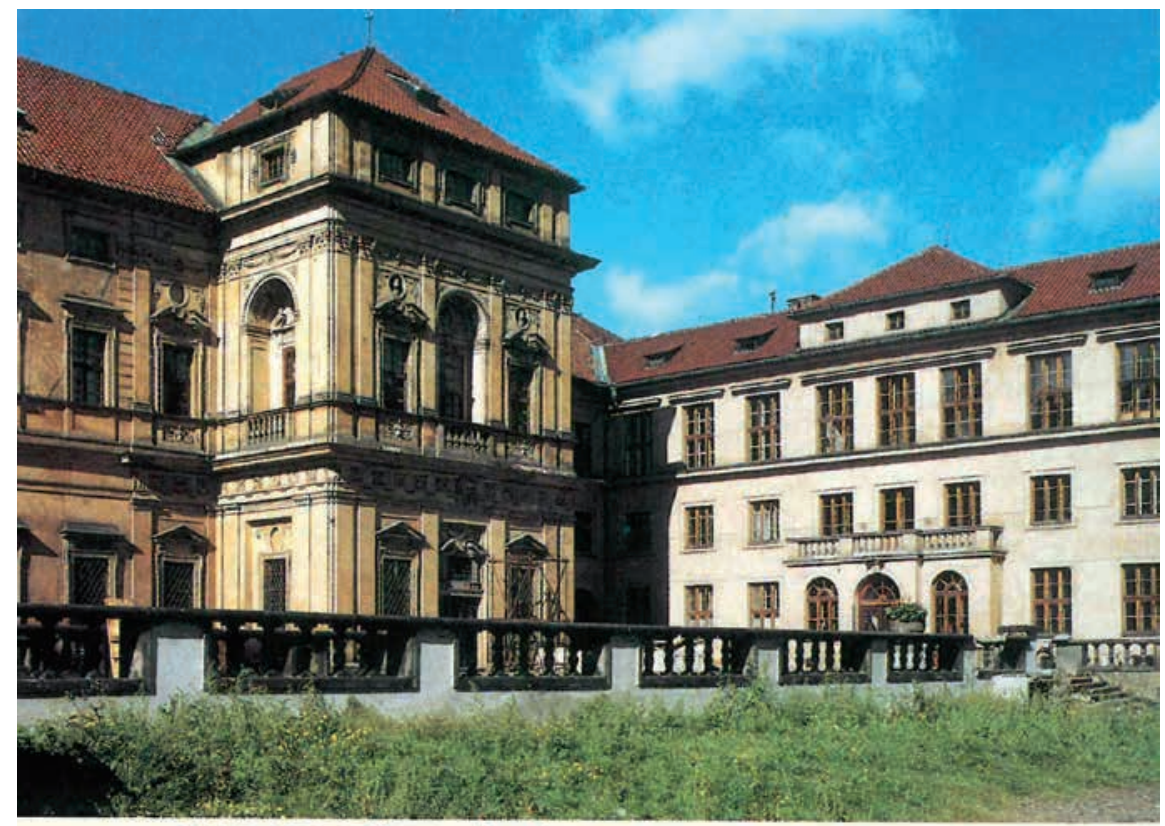

MUZEUM TĚLLSNÉ VÝCHOVY A SPORTU - PRAHA
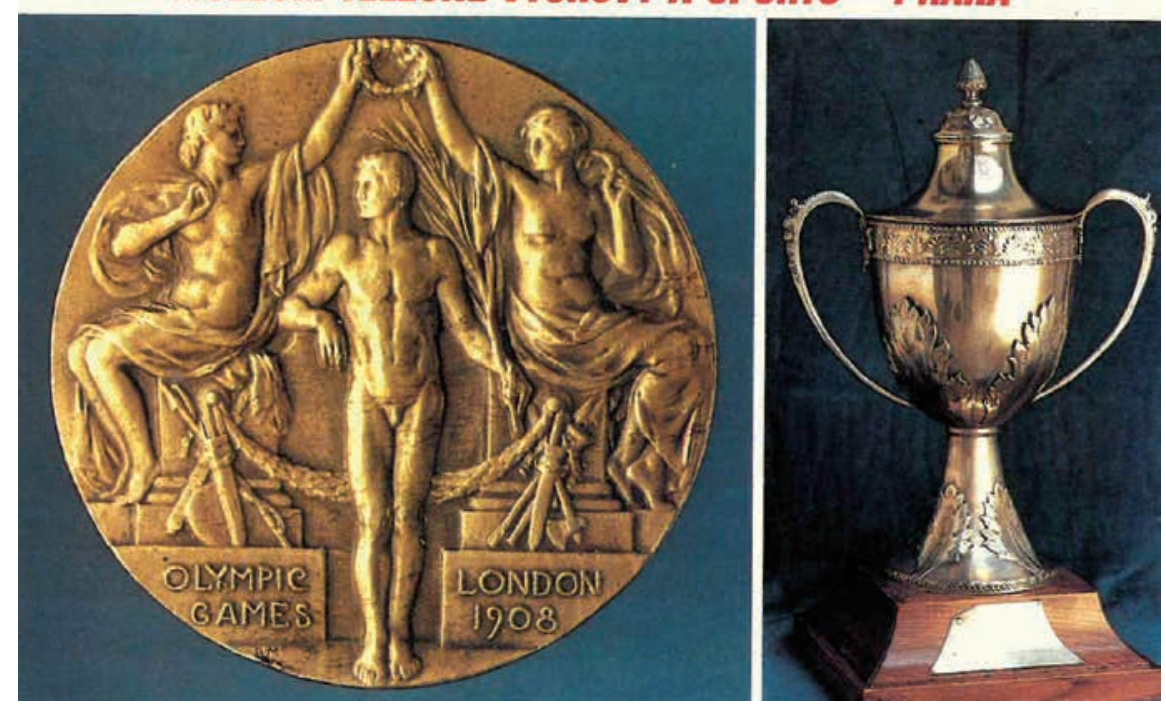

Muzeum tělesné výchovy a sportu, pohlednice, 70.-80. léta 20. století

5 Ibidem, s. 19-20. Srov. také ŠTURSOVÁ, Květoslava. Nástin dějin československého tělovýchovného a sportovního muzejnictví 1, In Muzejní a vlastivědná práce, 1990, roč. 28 č. 4 , s. $136-154$.

6 Ibidem, s. 23. Srov. také ŠTURSOVÁ, Květoslava. Nástin dějin československého tělovýchovného a sportovního muzejnictví 2, In Muzejní a vlastivědná práce, 1990 , roč. 28 , č. 4, s. $193-199$.

7 Ibidem, s. 24-32. Srov. také ŠTURSOVÁ, Květoslava. Nástin dějin československého tělovýchovného a sportovního muzejnictví 3. Muzejní a vlastivědná práce, 1991, roč. 29, č. 1, s. 1-12. muzea stála řada osobností českého sportu a olympismu, jako např́klad tehdejší předseda Československého olympijského výboru Josef Gruss či Rudolf Richter. ${ }^{6}$ Po roce 1948 došlo ke sloučení všech zmíněných muzejních institucí do Státního muzea československé tělesné výchovy a sportu se sídlem v Tyršově domě v Praze, které bylo zř́zeno k 1. únoru 1953. Vedle Muzea dr. M. Tyrše a J. Fügnera, muzea ČOS a Muzea československé tělesné výchovy a sportu se základem sbírek stal i sbírkový fond Československého výboru olympijského, včetně pozůstalosti zakladatele Českého olympijského výboru Jiř́ího S. Gutha-Jarkovského. Přes krátké období, kdy Státní muzeum tělesné výchovy a sportu působilo při Státním výboru tělesné výchovy a sportu, fungovalo v letech 1957-1972 jako samostatná rozpočtová organizace Ministerstva školství a kultury. Díky enormnímu nárůstu sbírek začala být z hlediska jejich uložení ke konci šedesátých let situace neúnosná. V roce 1961 získalo nové vedení muzea pro depozitární prostory budovu bývalého kláštera v Zaječově u Berouna. Do depozitáře byly přesunuty trojrozměrné sbírkové předměty, část knihovny a byla provedena revize sbírek. Od roku 1972 se muzeum stalo součástí Národního muzea jako jedno z jeho odborných oddělení. 7

Po roce 1989 tehdejší vedení navrhovalo osamostatnění muzea, nicméně $\mathrm{k}$ tomu nedošlo. V roce 1993 byl v restituci České obci sokolské vrácen Tyršův dům, muzeum bylo následně nuceno vyklidit dva sály a změnit název z Muzea tělesné výchovy a sportu na Tyršovo muzeum tělesné výchovy a sportu, o dva roky později pak bylo nuceno vyklidit další dva sály. Poslední ránu stálé expozici zasadily povodně v roce 2002, po nichž ČOS vypověděla muzeu smlouvu o nájmu nebytových prostor. Od té doby je tak Oddělení dějin tělesné výchovy a sportu zbaveno možnosti prezentovat výstavní formou svoji činnost s výjimkou dočasných expozic. Nejproblematičtější období přišlo v letech 2010-2015, kdy bylo na popud tehdejšího ředitele Historického muzea Pavla Douši 
Oddělení dějin tělesné výchovy a sportu začleněno jako Sbírka tělesné výchovy a sportu do Oddělení novodobých českých dějin Národního muzea. To znamenalo nejen personální diskontinuity, kdy se starší spolupracovníci od muzea v podstatě odklonili, tak i diskontinuitu z hlediska odborné činnosti a zejména ztrátu kontaktů jak v ČR, tak v zahraničí. Od roku 2016 funguje opět jako samostatné oddělení. Výrazný problém však představuje kontinuální pokles pracovníků, kteři o sbírky pečují. V roce 2003 sbírkový fond a muzejní expozici spravovalo 10 pracovníkư, ${ }^{8} \mathrm{v}$ současné době má oddělení $\mathrm{k}$ dispozici formálně 4 plné úvazky.

\section{Současný stav sbírky ODTVS}

Opačný, tedy rostoucí trend je patrný naštěstí v oblasti sbírek. Knihovna spravuje v současné době 30000 knihovních jednotek (z toho 1000 titulů periodik), trojrozměrná sbírka obsahuje 46000 zapsaných sbírkových předmětů, fotoarchiv 80000 zpracovaných fotografií, 9000 negativů, 6000 diapozitivů a 600 fotoalb. Sbírky zahrnují i audiovizuální kolekci, která je v současné době ve stadiu digitalizace. Archiv přesto, že je formálně vyčleněn, zůstává fakticky nedílnou součástí sbírkového fondu. Obsahuje celkem 262 archivních fondů a sbírek a sbírku 9500 plakátů.

\section{Nedávná a současná činnost oddělení}

Oddělení se i přes problematické peripetie ohledně restrukturalizací v Národním muzeu snaží představovat nejen témata týkající se českého a československého sportu a tělesné výchovy, ale též olympismu. $\mathrm{V}$ roce 2007 byl publikován průvodce po sbírkách Archivu dějin tělesné výchovy a sportu. ${ }^{9}$ V letech 2008 a 2010 vyšel přehled signovaných kreseb a obrazů, respektive signovaných plastik a sportovních trofejí, jehož autorkami byly H. Havránková, J. Schůtová a V. Saurová. ${ }^{10}$ V roce 2012 vyšel soupis olympionik $\mathrm{v}$ trojrozměrné sbírce od stejného autorského tria, publikace obsahuje stav předmětů $\mathrm{k}$ roku $2010 .{ }^{11}$ Od té doby řada předmětů přibyla, tudíž lze do budoucna uvažovat o rozšířené formě katalogu. $Z$ nedávných publikací se sbírkám věnuje publikace J. Schůtové Knihovna Sbirky tělesné výchovy a sportu. ${ }^{12} \mathrm{U}$ př́ležitosti XXXI. olympijských her byla vydána Móda pod olympijskými kruhy, jejímiž autorkami jsou Š. Rámišová a L. Swierczeková. Kniha popisuje vývoj olympijského nástupního oblečení v průběhu konání novodobých olympiád od jejich počátku až do letních olympijských her v Riu de Janeiru v roce 2016. ${ }^{13}$ Vedle toho se pracovníci oddělení podíleli i na dalších publikacích, $\mathrm{z}$ těch významnějších je potřeba zmínit kolektivní monografii StArt: Sport jako symbol ve výtvarném umění z per autorského kolektivu pod vedením Rostislava Šváchy, na kterém vedle drobných textů participovalo muzeum zejména z hlediska obrazového materiálu. ${ }^{14} \mathrm{~V}$ roce 2018 pak byly publikovány dvě monografie vycházející ze sbírkových fondů ODTVS, a to práce zpracovávající biografii a korespondenci Kateřiny Fügnerové (Manželka, matka, tchyně: dochované památky a korespondence Kateřiny Fügnerové) a publikace o dějinách sokolského kroje (S hrdostí nošený). ${ }^{15}$

Kromě ostatní odborné a popularizační činnosti ODTVS prezentovalo i řadu témat spjatých s českým sportem, tělesnou výchovou a olympijským hnutím výstavní formou. Expoziční činnost je poněkud problematická kvưli tomu, že již v podstatě dvě desetiletí nemá Oddělení dějin tělesné výchovy a sportu vlastní expozici a je odkázáno na výstavní plán Národního muzea, který se v posledních letech jevil z hlediska termínů a prostorů ovlivněných probíhající rekonstrukcí budov NM jako značně problematický. K olympijským hrám v Riu tak oddělení uspořádalo výstavu Olympijský plakát, která se konala 24. 6. - 2. 10. 2016 v Národním památníku na Vítkově. ${ }^{16} \mathrm{~V}$ rámci těchto olympijských her se ODTVS podílelo i na výstavě Poštovního muzea Vítězové a poražení. Neoydané známky a neuskutečněné olympiády, která se konala 24. 6. - 30. 9. $2016 \mathrm{v}$ prostorách expozice $\mathrm{v}$ klášteře ve Vyšším Brodě nedaleko Olympijského parku na Lipně. Větším výstavním celkem jak z hlediska rozsahu, tak doby konání,

\section{Ibidem, s. 64}

9 SrOV. SWIERCZEKOVÁ, Lucie. Průvodce po archivnich fondech a sbirkách Oddělení dějin tělesné výchovy a sportu Národního muzea. Praha: Národní muzeum, 2007, $88 \mathrm{~s}$. 10 Srov. SCHŮTOVÁ Jitka, SAUROVÁ, Vlasta, HAVRÁNKOVÁ, Hana. Signované kresby a obrazy Oddělení dějin tělesné výchovy a sportu Národního muzea. Praha: Národní muzeum, 2008, 188 s.; SCHŮTOVÁ, Jitka, HAVRÁNKOVÁ,

Hana, SAUROVÁ, Vlasta. Signované plastiky a sportovní trofeje: sbírka tělesné výchovy a sportu Národního muzea. Praha: Národní muzeum, 2010, 282 s.; SWIERCZEKOVÁ, Lucie. Průvodce po archivních fondech a sbirkách Oddělení dějin tělesné výchovy a sportu Národního muzea. Praha: Národní muzeum, 2007, 88 s. 11 SCHŮTOVÁ,

Jitka, HAVRÁNKOVÁ,

Hana a SAUROVÁ,

Vlasta. Olympionika v trojrozměrné Sbírce tělesné výchovy a sportu Národního muzea. 1. vyd. Praha: Národní muzeum, 2012, $152 \mathrm{~s}$.

12 SCHŮTOVÁ, Jitka. Knihovna sbírky tělesné výchovy a sportu ...a co jí předcházelo. Praha: Národní muzeum, 2015, $126 \mathrm{~s}$. 13 RÁMIŠOVÁ, Šárka a SWIERCZEKOVÁ, Lucie. Móda pod olympijskými kruhy: nástupové oblečení od Athén až po Rio. Praha: Mladá fronta, 2016, $158 \mathrm{~s}$.

14 ŠVÁCHA, Rostislav et al. StArt: sport jako symbol ve výtvarném umění. V Řevnicích Arbor vitae ve spolupráci s Českým olympijským výborem a Ústavem dějin umění $A V C \check{R}$, v.v.i., 2016, $315 \mathrm{~s}$

15 SCHU゚TOVÁ, Jitka. Manželka, matka, tchyně: dochované památky a korespondence Kateřiny Fügnerové.

Praha: Národní muzeum, 2018 463 s.; RÁMIŠOVÁ, Šárka.

$S$ hrdostí nošený: sokolský kroj, úbor a scénický kostým. Praha: Národní muzeum, 2018, $327 \mathrm{~s}$. 16 Olympijský plakát, 24. 6. 4. 9. 2016, Národní památník na Vítkově 


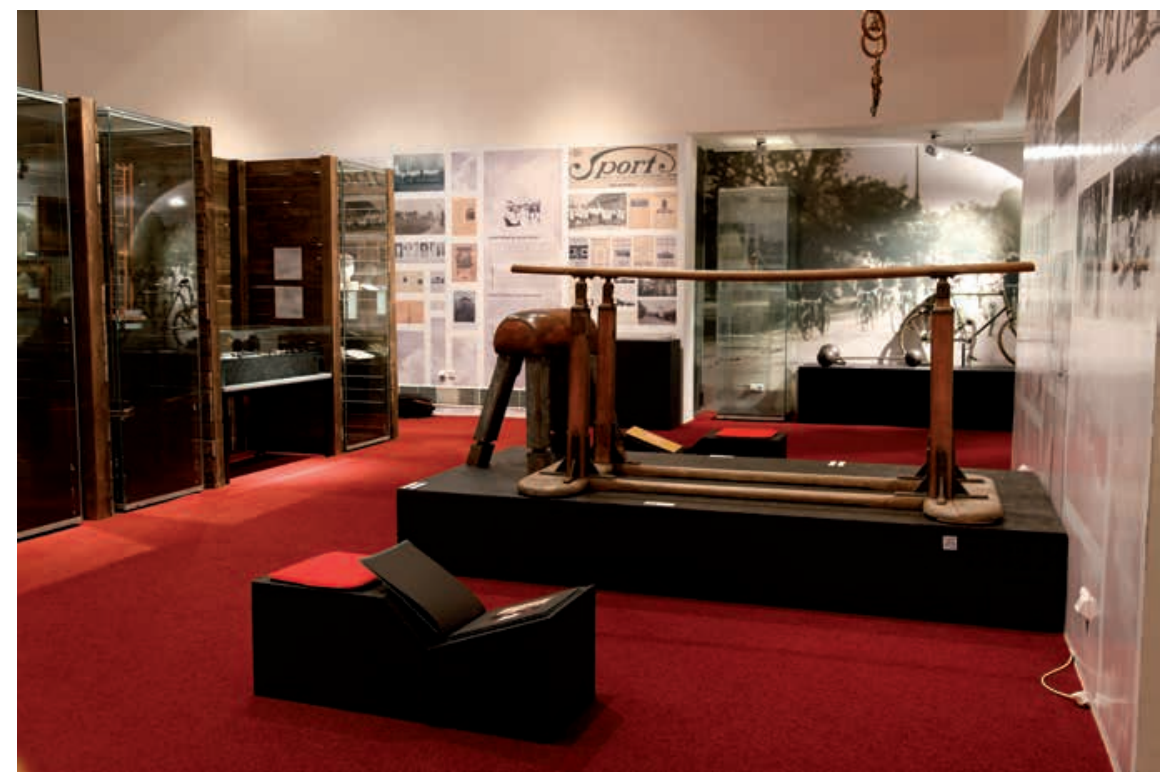

Výstava Sport za Velké války, Národní památník na Vítkově, 2017-2018

17 Srov. LOMÍČEK, Jan et al. Sport za velké války = Sport during the great war. Praha: Národní muzeum, 2017, 29 s. 18 Rudolf Richter -

7. 4. 1883 - 13. 1. 1962 , sportovní funkcionář, 1919-1951 pokladník ČsOV, od roku 1951 čestný člen tohoto výboru. $\checkmark$ letech 1903-1961 organizátor, startér a historik nejstaršího silničního běžeckého závodu na evropském kontinentu Běchovice - Praha. Dlouholetý funkcionár ČAAU a CUUUV. 19 "Přepište dějiny...!" Nagano 1998-2018, Národni památník na Vitkově, 2. 2. - 29. 4. 2018

20 Ni zisk, ni slávu!, ČOS,

Tyršův dưm, 20. 6. - 8. 7. 2018

li prodlevám při rekonstrukci nutné uspořádat $\mathrm{v}$ jiné instituci. Spoluúčast nabídlo Ostravské muzeum, a tak se výstava Ragby, hra síly, odvahy a bojovnosti uskutečnila v termínu 26. 9. - 3. 12. 2017 v Ostravě, rok poté, co bylo ragby opět zařazeno do programu letních olympijských her. V roce 2018 připravilo oddělení v rámci Národního památníku na Vítkově také menší expozici $\mathrm{k}$ dvacátému výročí úspěchu našich sportovců na XVIII. zimních olympijských hrách $\mathrm{v}$ japonském Naganu. ${ }^{19} \mathrm{~V}$ témže roce oddělení spolupracovalo na výstavě České obce sokolské Ni zisk, ni slávu!, která probíhala v rámci XVI. všesokolského sletu v sídle ČOS (a bývalém sídle muzea) v Tyršově domě. ${ }^{20}$ Ve stejném roce se oddělení podílelo na 16 dalších výstavních projektech, at již v rámci Národního muzea, či zápůjčkami sbírkových předmětů do dalších muzejních institucí. V následujícím roce oddělení připravilo ve spolupráci s Klubem českých turistů výstavu Zdrávi došli! ke 130. výročí založení KČT, prvního vydání klubového časopisu a první značené trasy. ${ }^{21}$ Ve spolupráci s ČOV v současnosti připravujeme výstavu k odloženým

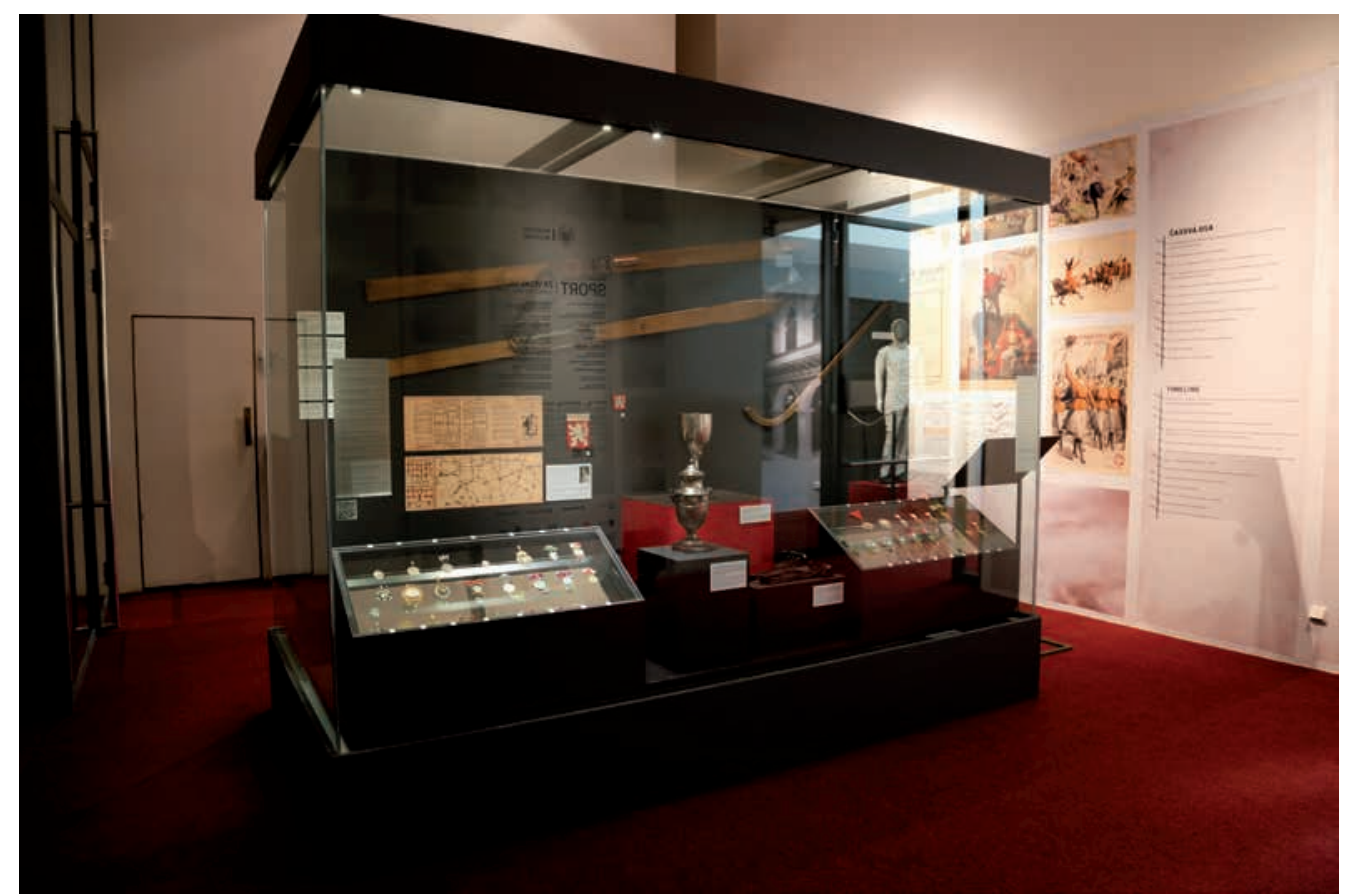

Výstava Sport za Velké války, Národní památník na Vítkově, 2017-2018 
olympijským hrám v Tokiu, zároveň je $\mathrm{v}$ př́ipravě i výstava $\mathrm{k}$ vývoji a historickým úspěchům českého volejbalu. Řada exponátů je prezentována i elektronickou časné době se na portálu nachází na 6000 zdigitalizovaných sbírkových předmětů se sportovní a olympijskou tematikou ze sbírek ODTVS.

\section{Sbírky ODTVS a ATVS}

Samotné sbírky Oddělení dějin tělesné výchovy a sportu a Archivu tělesné výchovy a sportu jsou členěny dle druhu materiálu. Archiv obsahuje prameny listinné povahy, diplomy, plakáty a mapy (i trojrozměrné). Fotografie a alba spravuje fotoarchiv, knižní publikace jsou zpracovávány specializovanou knihovnou. Trojrozměrná sbírka obsahuje kromě sportovní výzbroje a výstroje sportovní trofeje, plastiky, malby a kresby, prapory, olympijské oblečení, olympijské pochodně a jiné artefakty sportovní a tělovýchovné povahy, ale např́klad i suvenýry z cest. Ve sbírce audiovizuálních materiálů najdeme filmy, videokazety a gramofonové nahrávky. Ve formou pomocí portálu e-sbírky. ${ }^{22} \mathrm{~V}$ sou-

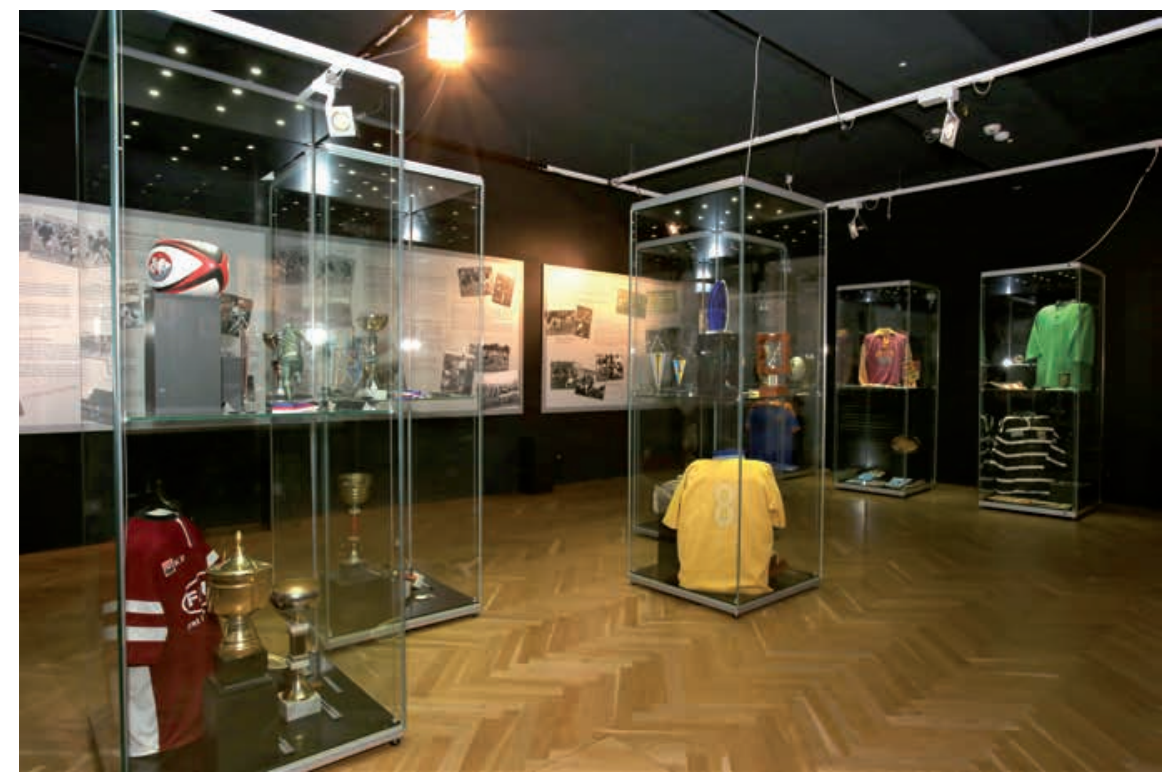

všech součástech sbírky se nacházejí rozsáhlé soubory položek s olympijskou tematikou, které muzeum získalo jak díky darům, tak i díky vlastní akviziční činnosti. Tyto materiály mapují vývoj českého olympismu od jeho počátků na přelomu 19. a 20 století až do současnosti.

\section{Archiv tělesné výchovy a sportu}

Archiv tělesné výchovy a sportu obsahuje kromě řady materiálů $\mathrm{k}$ dějinám olympijského hnutí, diplomů a plakátů s olympijskou tematikou také památky z pozůstalosti českých olympioniků, jak sportovců, tak funkcionářù. Za všechny

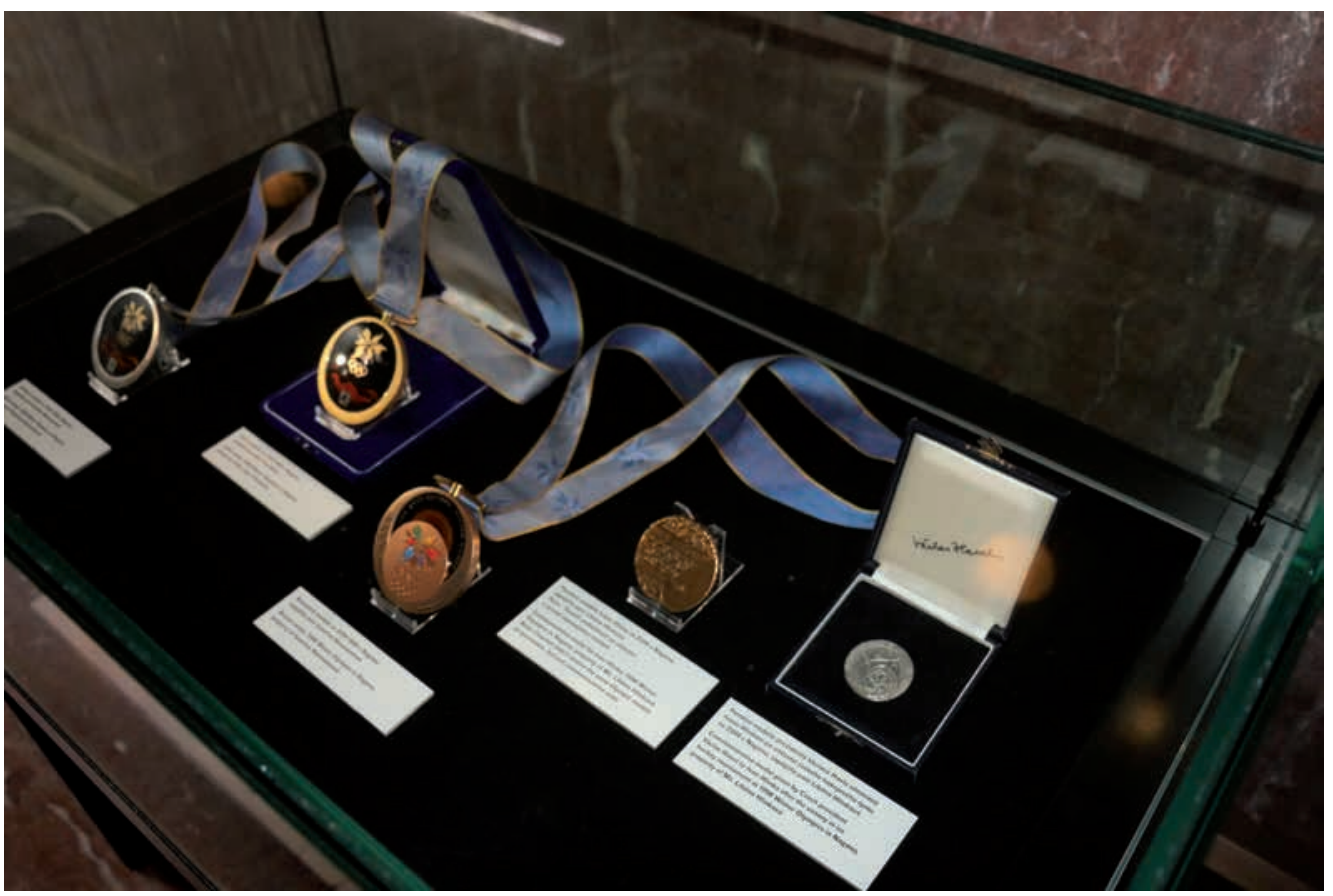

Výstava Přepište dějiny! Nagano 1998-2018, Národní památník na Vítkově, 2018
Výstava Ragby, hra sily, odvahy a bojovnosti, Ostravské muzeum v Ostravě, 2017
21 Zdrávi došli!

31. 5. - 1. 9. 2019, Národni památník na Vítkově 22 https://www.esbirky.cz/ hledat/podsbirka/81889, cit k 20. 8. 2020 


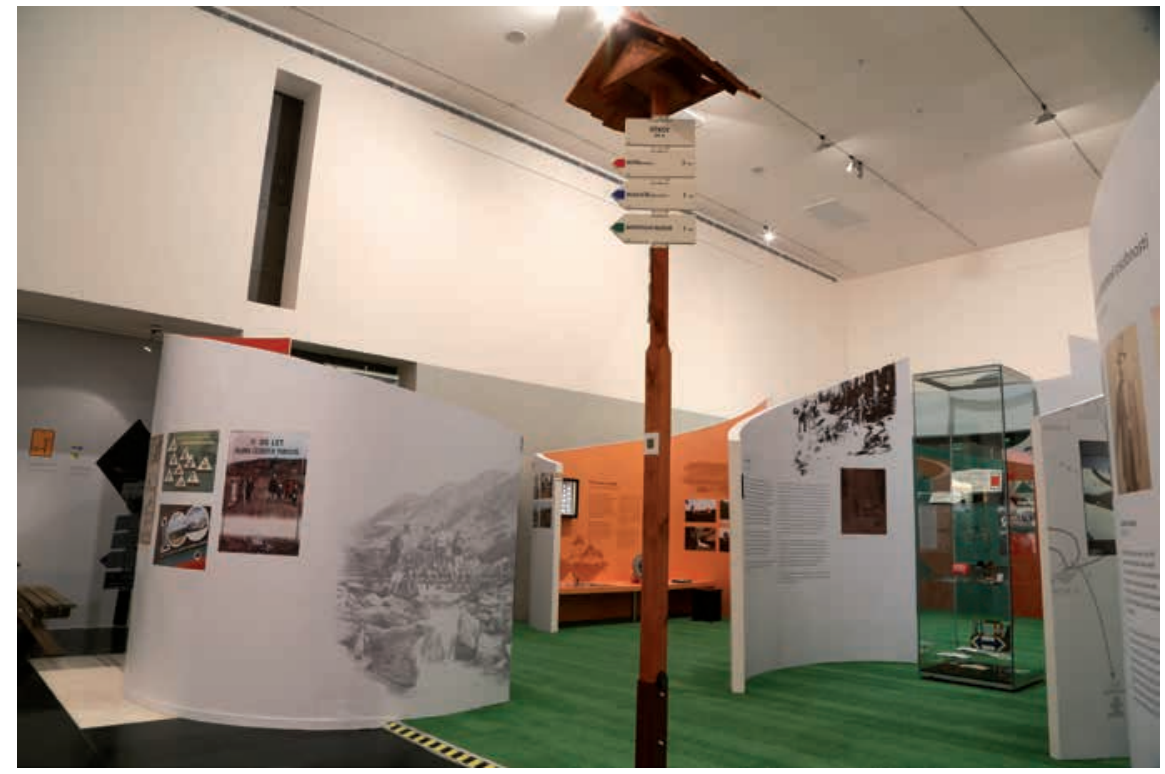

Výstava Zdrávi došli! K výročí Klubu českých turistů, Národní památník na Vítkově, 2019

23 Srov. SWIERCZEKOVÁ, Lucie. Prüvodce po archivních fondech a sbírkách Oddělení dějin tělesné výchovy a sportu Národního muzea. Praha: Národní muzeum, 2007, $88 \mathrm{~s}$ Heřmánka, Františka Doudu, Hanu
Maškovou a další. Rozsáhlá je i pozůstalost sportovního novináře Josefa Laufera. ${ }^{23}$

\section{Trojrozměrná sbírka ODTVS}

Celou řadu unikátních sbírkových předmětů z dějin českého i světového olympijského hnutí pak obsahuje trojrozměrná sbírka ODTVS. Vzhledem k historii svého formování obsahuje sbírka řadu exponátů, které se vztahují k historii sokolského hnutí. Patří sem jak osobní předměty zakladatelů Sokola Jindřicha Fügnera a dr. Miroslava Tyrše z pozůstalosti Renáty Tyršové, tak i předměty upomínající na další sokolské osobnosti. Vedle toho sbírka obsahuje řadu artefaktů vztažených jak k významným sokolským akcím, tak i k činnosti jednotlivých složek Sokola. Dějiny sokolského hnutí také ilustruje řada uměleckých děl, často od předních osobností českého výtvarného umění. Ve sbírce se nacházejí i připomínky počátků olympijského hnutí - pamětní medaile $\mathrm{k}$ připomínce Mezinárodního kongresu o obnově olympijských her konaného v Pařiži v roce 1894, stejně jako pamětní medaile připomínající první novodobé olympijské hry v Aténách v roce 1896.

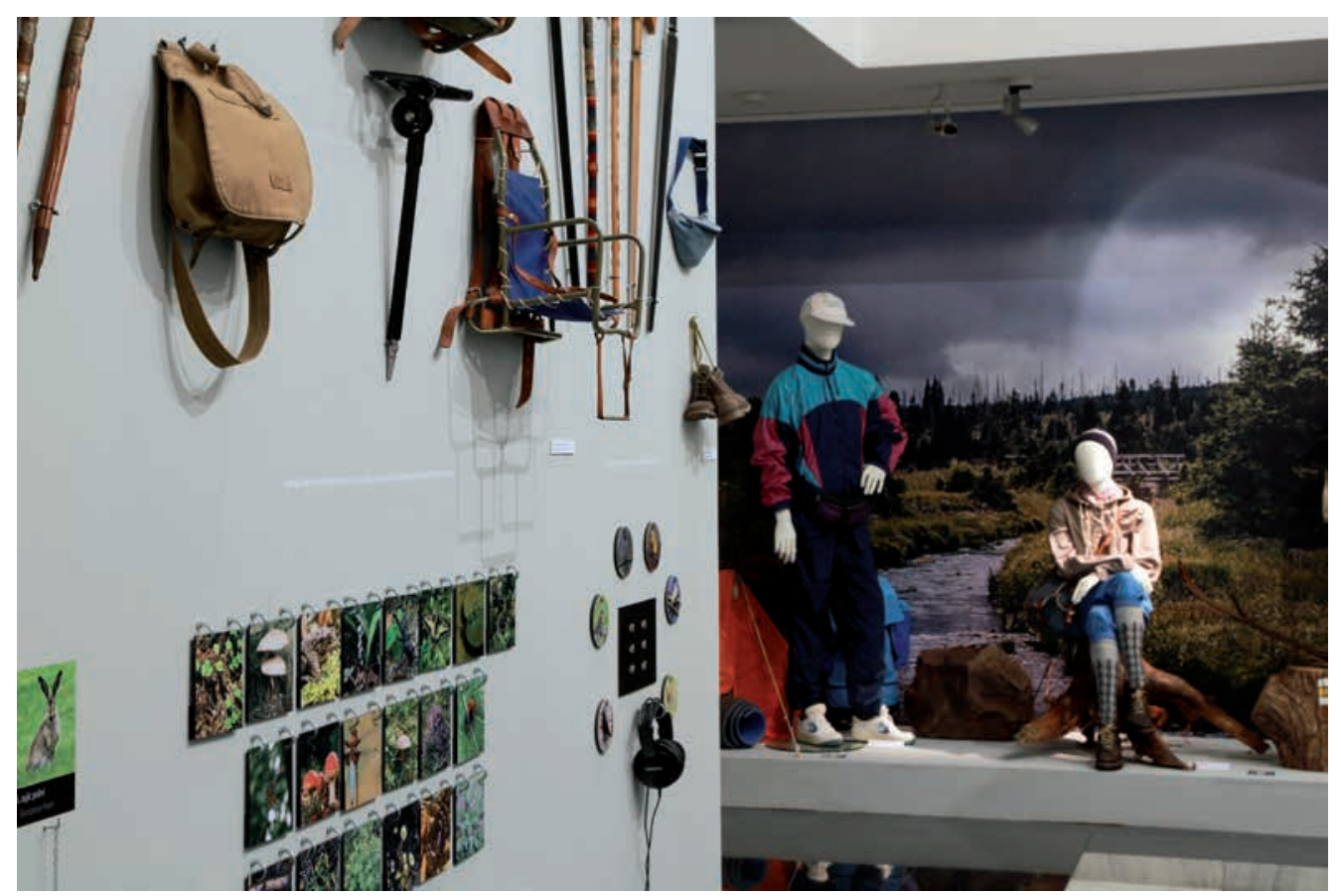

Výstava Zdrávi došli! K výročí Klubu českých turistů, Národní památník na Vítkově, 2019 
Sbírka obsahuje i další připomínky prvních olympiád, např́klad praporky s českým lvem, které doprovázely českou výpravu při slavnostním nástupu u př́ležitosti zahájení olympijských her ve Stockholmu v roce 1912. Najdeme zde i upomínky na další olympijské hry a kongresy, jako byl např́íklad VIII. mezinárodní olympijský kongres uspořádaný v roce 1925 v Praze, kde bylo rozhodnuto o konání zimních olympijských her. Vedle toho se ve sbírce nachází řada sbírkových předmětů mapujících vývoj jednotlivých sportovních odvětví, stručně od zimních sportů po letní, od úpolových sportů (box) po duševní sporty (šachy).

Ve sbírce sportovních trofejí a ocenění figurují na prvním místě první československá zlatá olympijská medaile, kterou získal v roce 1924 na OH v Paříži Bedřich Šupčík $\mathrm{v}$ dnes již neolympijské disciplíně ve šplhu bez prírazu na sedmimetrovém laně, stejně jako vůbec první česká olympijská medaile (bronzová) získaná Vilémem Goppoldem z Lobsdorfu na $\mathrm{OH} v$ roce 1908 v Londýně v šermírských soutěžích. Sbírka vedle toho obsahuje i řadu dalších ocenění, jako naprŕklad zlaté medaile Františka Ventury a Ladislava Váchy z Amsterodamu 1928, Ludvíka Daňka z Mnichova 1972. K dalším cenným kovům patří i stříbrné olympijské medaile boxera Jana Heřmánka z olympijských her 1928, Věnceslavy Peškové a Vlasty Děkanové z Berlína 1936, bronzové medaile Františka Doudy z OH 1932 v Los Angeles, Hany Maškové z Grenoblu 1968 aj. ${ }^{24}$

Sbírka obsahuje řadu cenných plastik od předních českých sochařů (Horejc, Lidický, Myslbek, Mařatka, Sucharda, Španiel aj.). Ve sbírce se nachází také dílo českého sochaře Jakuba Obrovského, jehož bronzová postava nahého atleta $\mathrm{s}$ oštěpem $\mathrm{v}$ ruce $\mathrm{s}$ názvem Vraždící Odysseus se umístila na třetím místě $\mathrm{v}$ umělecké soutěži na X. olympijských hrách v roce 1932 v Los Angeles. Sbírka uchovává též stř́ibrnou putovní cenu dr. Jiř̌́ho Stanislava Gutha-Jarkovského, nejvyšší vyznamenání Československého, respektive Českého olympijského výboru, kterou $k$ poctě prvního předsedy založilo
Kuratorium olympijského fondu. Cena byla udělována v letech 1934-1948 a následně po roce 1994 bylo její udělování obnoveno. Plastika samotná je dílem sochaře Otakara Španiela a znázorňuje bohyni Niké s vavř́novou ratolestí ve vztyčené pravici na mramorovém podstavci se jmény nositelů ceny. ${ }^{25}$

Vedle větších i drobných plastik obsahuje sbírka řadu dalších uměleckých předmětů - sem patř́i zejména sbírka kreseb a obrazů, obsahující díla vztahující se nejen k historii Sokola, ale i dalších sportovních odvětví. Sbírka obsahuje například návrhy plakátů $\mathrm{k}$ všesokolským sletům a dalším tělovýchovným a sportovním akcím, ale také portréty osobností naší tělovýchovy a sportu či umělecká díla s širší sportovní tematikou, a to od řady předních jmen českého výtvarného umění (Mánes, Marold, Preissler, Mucha, Ženíšek, Benka aj.. $)^{26}$

Trojrozměrná sbírka uchovává i součásti sportovní výstroje a výzbroje, slavnostních nástupních oblečení českých a československých výprav na letních i zimních olympijských hrách. Z nejvýznamnějších artefaktů $\mathrm{v}$ této oblasti je možné zmínit tretry největších osobností světové atletiky - čtyřnásobného olympijského vítěze Emila Zátopka, stejně jako trojnásobného olympijského vítěze Jana Železného. Ve sbírkách se také nachází Železného oštěp, se kterým v roce 1996 hodil světový rekord $(98,48 \mathrm{~m})$, stejně jako oštěp Dany Zátopkové. Z hlediska sportovní výstroje a výzbroje obsahuje sbírka také soubory umožňující ilustrovat vývoj sportovního vybavení, a to jak z oblasti lehké atletiky, tak tenisu, šermu, lyžování, sáňkařského sportu či fotbalu, ragby nebo ledního hokeje.

Vyjmenovat všechny cenné a zajímavé artefakty vzhledem $\mathrm{k}$ rozsahu sbírky i textu nelze, řada $z$ uchovávaných předmětů má své hodnoty $\mathrm{v}$ různých rovinách historické, symbolické, osobní. Jedním z nejnovějších prrírůstků mapujících dějiny českého olympismu je olympijský řád Emila Zátopka, který obdržel v roce 1989, či zlatá medaile gymnastky Zdeňky Honsové z XIV. letních olympijských her v Londýně 1948.
24 Srov. SCHŮTOVÁ, Jitka, HAVRÁNKOVÁ, Hana, SAUROVÁ, Vlasta. Olympionika v trojrozmèrné Sbírce tělesné výchovy a sportu Národního muzea. Praha: Národní muzeum, 2012, $152 \mathrm{~s}$. 25 Srov. SCHŮTOVÁ, Jitka, HAVRÁNKOVÁ, Hana, SAUROVÁ, Vlasta. Signované plastiky a sportovní trofeje: sbírka tělesné výchovy a sportu Národního muzea. Praha: Národní muzeum, 2010, $282 \mathrm{~s}$.

26 Srov. SCHU゚TOVÁ, Jitka, SAUROVÁ, Vlasta, HAVRÁNKOVÁ, Hana. Signované kresby a obrazy Oddělení dějin tělesné výchovy a sportu Národního muzea. Praha: Národní muzeum, 2008, $188 \mathrm{~s}$. 


\section{Fotoarchiv ODTVS}

Fotoarchiv zahrnuje bohaté materiály se sokolskou, obecně sportovní i olympijskou tematikou prezentující sportovní a tělovýchovné dějiny na našem území v podstatě od vzniku fotografie a olympijské hnutí od jeho vzniku až do současnosti. K unikátním fotografiím patří mimo jiné snímky zobrazující zakladatelské osobnosti sokolského hnutí, stejně jako jeho památná místa či akce, vyobrazení organizačního výboru a členů Mezinárodního olympijského výboru, dokumentující první zasedání MOV aj. Vedle toho sbírky obsahují řadu unikátních fotografií mapujících jak oficiální sportovní akce, tak i zázemí sokolských sletů či olympijských her. Fotoarchiv obsahuje i jedinečné soubory $z$ dějin českého sportu a tělesné výchovy, kam patří např́klad soubor fotografií Františka Illka. Rada fotografií zobrazuje historii sokolského hnutí, a to jak z pohledu ústředních institucí, tak dílčích sokolských jednot. Dále fotografická sbírka zahrnuje i dějiny řady dalších sportovních organizací, odvětví či osobností.

\section{Knihovna ODTVS}

Knihovna ODTVS obsahuje unikátní soubor publikací a periodik, které se vztahují $\mathrm{k}$ dějinám tělesné výchovy a sportu nejen na našem území, ale i jinde ve světě. Součástí knihovny je samostatně dochovaný knihovní soubor pocházející z Tyršovy knihovny, který zahrnuje i tisky z bývalé knihovny Jindřicha Fügnera a několik starých tisků. $V$ knihovně zakladatelů Sokola jsou uložena díla z mnoha společenskovědních oborů, převážně z 19. století. Velmi cenný je rovněž dochovaný celek šachové knihovny Josefa Vladimíra Štefanydese, jenž obsahuje necelých 900 svazků, včetně několika starých šachových tisků z 18. století a několika desítek titulů šachových periodik z celého světa. Vedle toho knihovna obsahuje na 1000 titulů sportovních periodik, teoretické a historické práce, memoáry aj. ${ }^{27}$

\section{Sportovní muzea a stálé expozice v ČR - nástin situace}

Dlouhodobá absence stálé sportovní expozice a omezené možnosti prezentace nových akvizic i další odborné činnosti oddělení přispěly ke ztrátě povědomí o sportovních sbírkách v Národním muzeu obecně. Situaci do jisté míry odlehčují dočasné tematické výstavy, které však nemohou soustavnou komunikaci s laickou i odbornou veřejností v plném rozsahu suplovat. S postupným odklonem od možností trvalé prezentace sbírkové činnosti Národního muzea na tomto poli začaly činnost hlavní muzejní instituce v zemi suplovat sportovní síně slávy, regionální či soukromá muzea.

Oficiálně př́ístupné síně slávy se týkají zejména nejmasovějších sportů v ČR. Hokejová sín slávy, oficiálně Síň slávy českého hokeje (ČSLH), kterou spravuje Český svaz ledního hokeje, byla otevřena v roce 2008 ke stému výročí českého hokeje. Původní expozice, př́stupná pouze pro VIP osoby, byla umístěna $\mathrm{v}$ rámci jedné z konferenčních místností v pražské O2 Aréně. V širší míře byla veřejnosti zpřístupněna až v roce 2015 v pražském nákupním centru Galerie Harfa, kdy se ČSLH snažil vyřešit nedostatečnou komunikaci s veřejností otevřením klasické komerční interaktivní expozice. Vše zároveň souviselo s rekonstrukcí sídla svazu a jeho přesunem do kancelářského komplexu na pražské Harfě. V současné době tak funguje ve výstavním prostoru expozice zaměřená jak na vývoj ledního hokeje obecně, tak i na vývoj tohoto sportovního odvětví v českých zemích. Součástí expozice je i vlastní Sín slávy, do které jsou každoročně uváděny osobnosti z historie českého a československého hokeje. Stálá expozice je doplněna o dočasné výstavy Pražský hokej, Češi v NHL (stav k roku 2020). Vzorem síně slávy se stala nepoměrně větší expozice Síň slávy NHL, která je umístěna v kanadském Torontu. ${ }^{28}$ V souvislosti s oficiální českou hokejovou síní slávy je potřeba zmínit i neoficiální Hokejovou síň českého hokeje, která vznikla ve středočeských Lánech. 
Soukromá expozice věnovaná dějinám československého hokeje obsahuje mnohé velmi zajímavé a cenné artefakty. Je založená na sbírce pana Josefa Hoška, který se sbírání sportovních memorabilií věnoval dlouhá léta. Expozice představuje přes třicet osobností českého hokeje, včetně osobních předmětů. Pro veřejnost bylaotevřena v roce $2014 .{ }^{29}$

Obdobně jako Český svaz ledního hokeje si zrrídila Sín slávy i Fotbalová asociace ČR (FAČR). Expozice byla otevřena v roce 2015 u prríležitosti Mistrovství Evropy hráčů do 21 let, které se konalo v ČR. Expozice je nepoměrně skromnější než ta hokejová a je umístěna $\mathrm{v}$ novém sídle FAČR na pražském Strahově. Na rozdíl od hokejové síně slávy je veřejnosti prístupná zdarma. ${ }^{30} \mathrm{Z}$ jednotlivých klubů má pravděpodobně nejreprezentativnější expozici klubové historie pražská Slavia. Slavia Museum je umístěno $\mathrm{v}$ rámci stadionu v pražském Edenu a snese srovnání s expozicemi významných zahraničních fotbalových klubů. Je umístěno ve dvou patrech na $1200 \mathrm{~m}^{2}$, přičemž jedna část je věnována vlastní klubové historii, druhá pak dočasným expozicím. ${ }^{31}$

Pravděpodobně nejvíce regionálních expozic je věnováno historii lyžování. Do této kategorie spadá zejména expozice Bílou stopou - kapitoly z dějin českého lyžování do roku 1938 v Krkonošském muzeu v Jilemnici spadajícím pod Správu Krkonošského národního parku, která je umístěna v budově bývalého panského pivovaru. Expozice mapuje historii lyžování od prvního importu lyží do českých zemí až do roku 1938. Zaměřuje se také na německé lyžaře v českých zemích. Celkově expozice zasazuje vývoj lyžování v českých zemích do evropského kontextu. Obsahuje řadu cenných artefaktů od vlastního lyžařského (a sáňkařského) vybavení přes sportovní ocenění, dobové fotografie až po oblečení ${ }^{32}$ Další expozicí mapující dějiny lyžařského sportu na našem území je Ski Muzeum - Lyžařské muzeum v Harrachově, které bylo otevřeno $v$ roce 2017. Základem muzea se staly sbírky Stanislava a Josefa Slavíkových, kteří také stojí za vytvořením vlastní expozice. Ta ilustruje vývoj lyžování v Harrachově, ale obsahuje i řadu dalších cenných artefaktů, od jedněch z nejstarších lyží po pohár pro vítěze Mistrovství světa v letech na lyžích v roce 1983, které se uskutečnilo právě v Harrachově, a další exponáty z historie jak skoků na lyžích, tak i běžeckého lyžování. ${ }^{33} \mathrm{~V}$ souvislosti s tímto odvětvím

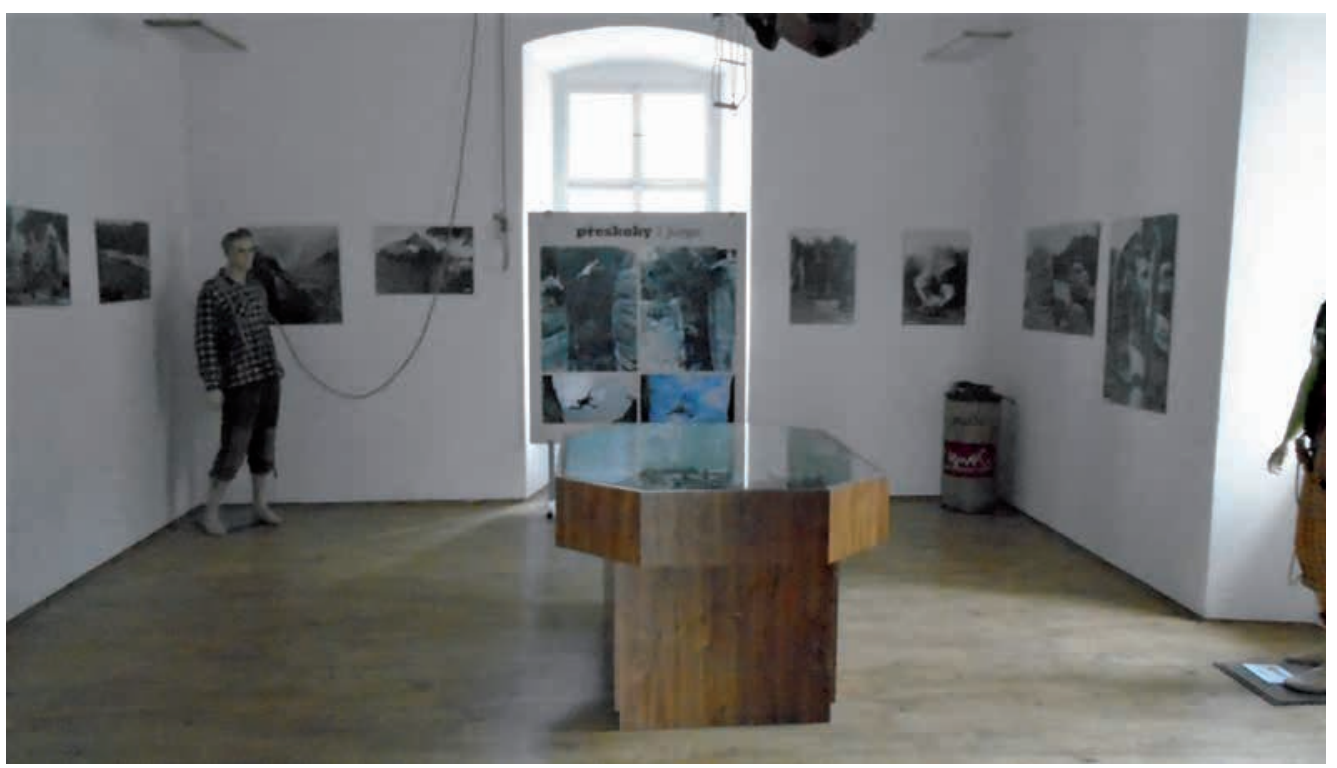

Horolezecké muzeum, Zámek Adršpach, stav k roku 2016
29 https://www.hokejovasin. czl, cit. k 20.8. 2020, Stránky obsahují i prezentaci jednotlivých osobností českého hokeje, kterým je expozice věnována, a možnost virtuální prohlídky expozice.

30 https://sinslavy.fotbal.cz/o-sini-slavy/p189, cit. k 20. 8. 2020. 31 Srov. https://www.slavia.czl museum.asp, cit. k 20. 8. 2020. 32 Srov. https://www.krnap.czl km-jilemnicel, cit. k 20. 82020. 


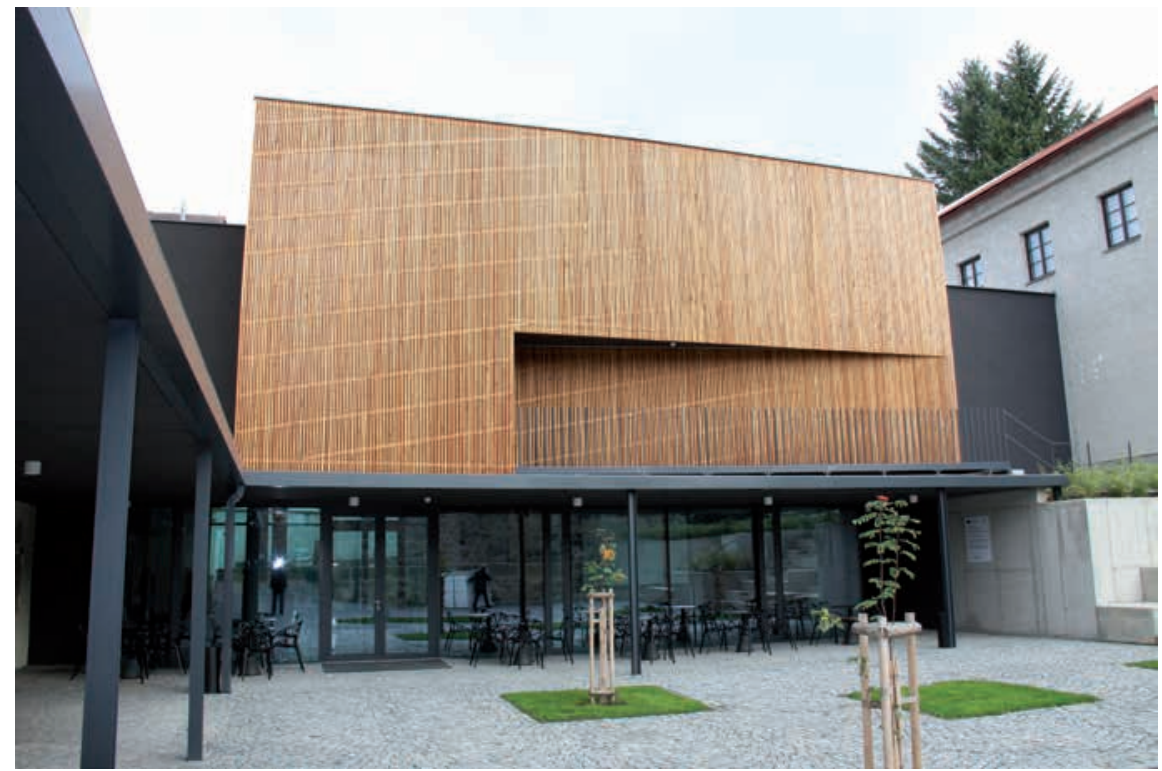

Expozice horolezectví Z Českého ráje až na vrcholy světa, Muzeum Českého ráje v Turnově, stav k roku 2019

33 Srov. http://skimuzeum.czl, cit. $k$ 20.8. 2020.

34 Srov. https://www.detoa. cz/muzeum-vyroby-hracek, cit. $k 20.8$ 2020. Rudolf Burkert získal bronzovou medaili na ZOH 1928 ve Sv. Mořici.

35 Srov. https://hm.nmnm. czlstale-expozicel

cit. k 20. 82020.

36 Srov. http://www.slonek.cz/nabidka/historiel, cit. $k$ 19. 8. 2020.

37 Srov. http://www.muzeum -lyzovani.cz/muzeum-lyzovani, cit. $k$ 20.8. 2020;

38 Srov. https://www.obecadrspach.cz/zamek-1/horolezecke-muzeum/, cit. k 17. 8. 2020. lyžařského sportu je potřeba zmínit také drobnou expozici Slavní sportovci věnovanou zejména skokanovi na lyžích Rudolfu Burkertovi, sudetskému Němci, který byl prvním československým medailistou na zimních olympijských hrách. Je umístěna v jedné z výstavních síní v rámci Muzea výroby hraček firmy Detoa v Jiřetíně pod Bukovou. ${ }^{34}$

Dílčí expozice Výroba lyží a vývoj lyžování věnovaná místní historii lyžařského sportu a výrobě lyží je součástí Horáckého muzea v Novém Městě na Moravě, které vlastní také sbírku sportovní výzbroje, stav $k$ roku 2019 výstroje a artefaktů mapujících vývoj lyží a vázání. Základ sbírky spadá do druhé poloviny padesátých let 20 . století, kdy byla instalována první lyžařská expozice. ${ }^{35} \mathrm{~V}$ Novém Městě na Moravě bylo též zpřístupněno Muzeum lyží a lyžařského vázání, které představuje soukromou sbírku rodiny Slonkových, dlouholetých výrobců lyží. ${ }^{36} \mathrm{~V}$ budoucnosti by také měly vzniknout dvě expozice mapující historii českého lyžování, a to $\mathrm{v}$ Janově nad Nisou $^{37}$ a Dolní Branné, kde připravuje expozici jeden z předních českých lyžařských historiků Aleš Suk.

Ve druhém desetiletí nového tisíciletí se také začaly formovat expozice věnované horolezectví. První z nich byla expozice Horolezecké muzeum - Expozice adršpašského lezení věnovaná místní horolezecké historii a pískovcovému lezení, která vznikla pod patronací Českého horolezeckého svazu na zámku v Adršpachu. Expozice není příliš velká a za využití jednoduchých výstavních prostředků stručně nastiňuje historický vývoj tohoto sportovního odvětví. ${ }^{8}$ V září roku 2019 byla otevřena obsahově nepoměrně bohatší Expozice horolezectví

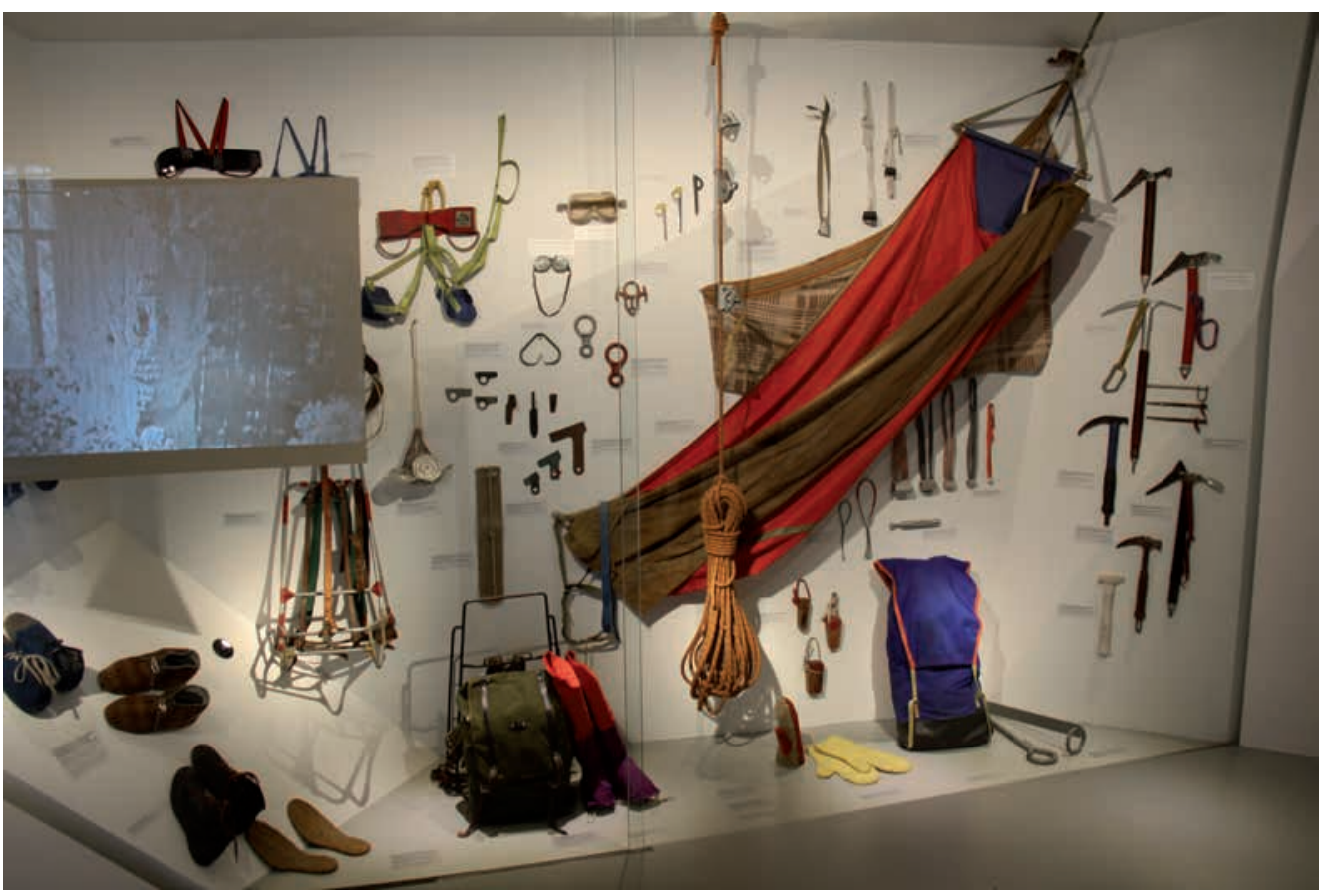

Expozice horolezectví - Z Českého ráje až na vrcholy světa, Muzeum Českého ráje v Turnově 
- Z Českého ráje až na vrcholy světa v Muzeu Českého ráje v Turnově. Vznikla za podpory evropského projektu přeshraniční spolupráce mezi ČR a Saskem. V rámci tohoto projektu byla vytvořena i horolezecká výstava v saském Bad Schandau. Turnovská expozice obsahuje vedle řady interaktivních prvků a videomappingu i mnoho exponátů mapujících historii horolezectví v oblasti Českého ráje i českého zdolávání světových vrcholů. Součástí projektu, který byl v rámci expozice také využit, byl sběr informací od pamětníků, stejně jako archivní studium. Vše posloužilo jako základ informací pro digitální archiv, který je ve formě databáze či encyklopedie ve výstavě využit. ${ }^{39} \mathrm{~V}$ řijnu 2020 získala expozice Cenu Gloria musealis za muzejní počin roku 2019.

Samostatnou kapitolu představují muzea věnovaná cyklistice a motoristickým sportům. Státní muzeum tělesné výchovy a sportu spravovalo do sedmdesátých let 20. století jeden z největších souborů věnovaných dějinám cyklistiky na našem území. V rámci restrukturalizace byl tento sbírkový soubor historických kol v sedmdesátých letech převeden do Národního technického muzea (NTM), kde se nachází dodnes. Vedle sbírek NTM se historii cyklistiky v českých zemích věnují i další regionální expozice. Do této kategorie spadá např́klad Muzeum kol v Boskovštejně, které vedle řady exponátů mapujících vývoj světové i české cyklistiky, z nichž některé pocházejí již z druhé poloviny 19. století, vlastní i unikátní sbírku plakátư. ${ }^{40}$ Patřilo sem např́íklad i První české muzeum cyklistiky umístěné na zámku v Nových Hradech, to však bylo ke konci roku 2017 zrušeno. Dílčích expozic a výstav, které se věnovaly a věnují historii cyklistiky i motoristických sportů, je v ČR celá řada a jejich výčet přesahuje rámec toto textu. ${ }^{41}$

Z hlediska historie dalších sportovních odvětví je potřeba zmínit ještě golf a Golf Muzeum Ypsilon, které začalo vznikat $\mathrm{v}$ roce 2016 a bylo otevřeno $\mathrm{v}$ golfovém resortu Ypsilon (Ypsilonka) u Liberce. Jde o projekt Vítězslava Hoffmanna, který se věnuje dlouhodobě historii golfu a stojí

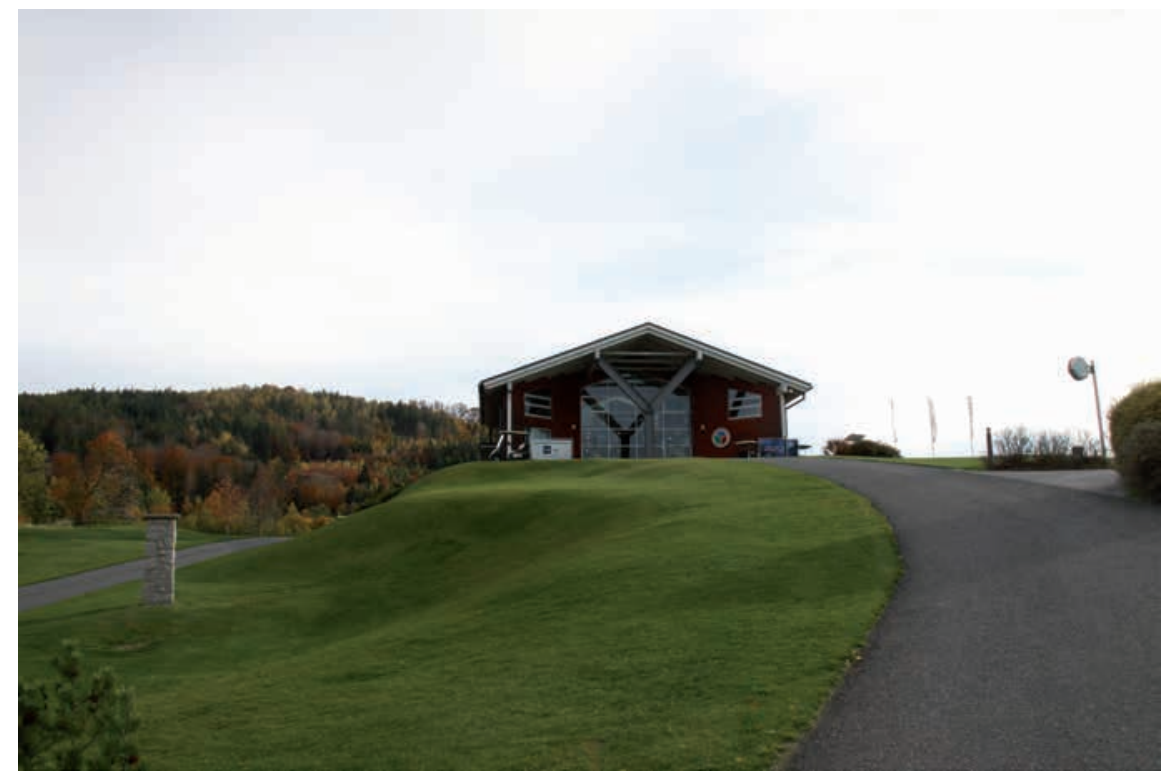

jak za vytvořením bohatého sbírkového základu, tak za realizací vlastní expozice. Součástí golfového muzea je vedle vlastní expozice i knihovna nabízející př́ípadným zájemcům o toto sportovní odvětví možnost studia. ${ }^{42}$

Na závěr stručného soupisu je třeba ještě zmínit stálou expozici věnovanou zápasníku Gustavu Frištenskému, umístěnou $\mathrm{v}$ městském muzeu v Litovli. Za její realizací stojí Zdeňka Frištenská, která je praneteří slavného zápasníka a zároveň působí jako ředitelka muzea. ${ }^{43}$ Expozice je věnována osobnímu životu i sportovním úspěchům Gustava Frištenského, Národní muzeum se na ní podílí zapůjčením předmětů z Frištenského pozůstalosti, které do sbírek tehdejšího Státního muzea sportu a tělesné výchovy věnoval jeho bratr.

Vedle výše uvedeného výčtu stálých expozic jistě existují v rámci České republiky i další, řada projektů také zanikla, sem bylo možno zařadit např́ílad ambiciózní projekt Muzea sportu v Plzni, které bylo otevřeno zprvu v Plzni-Roudné a později přesunuto do objektu plaveckého bazénu v Plzni-Lochotíně. Kompletní výčet expozic přesahuje rámec tohoto textu, nicméně u většiny sportovních odvětví je patrný trend, kdy jak oficiální zastřešující orgány a sportovní svazy, tak jednotlivci reagují na absenci instituce, která by soustavně prezentovala historii českého sportu a tělesné výchovy, a zaplňují její místo vlastními výstavními projekty. V souvislosti $\mathrm{s}$ tím je patrný i rostoucí trend $\mathrm{v}$ počtu výpůjček sportovních sbírek z regionálních muzejních institucí, kdy kurátoři trojrozměrné sbírky ODTVS řeší každoročně
Golf Muzeum Ypsilon, stav k roku 2020

39 Srov. https://www.muzeum-turnov.czlexpozice/horolezectvil, cit. $k$ 19. 8. 2020. Za odbornou prípravou výstavy Marek.

40 https://www.muzeumkol. eul, cit. k 17. 8. 2020.

41 Soupis jak stálých expozic, tak dílčích výstav, které byly realizovány od roku 2011 do současnosti, je možné dohledat na https://www.sterba-bike.cz/category/ceska-republi$k a$ ?offset=0, cit. $k$ 19. 8. 2020. 42 https://ygolfmuzeum.czl, cit. k 20. 8. 2020.

43 http://www.muzeumlitovel. cz/cs/vystavy/gustav-fristensky. stáli Alžběta Kulišková a David 


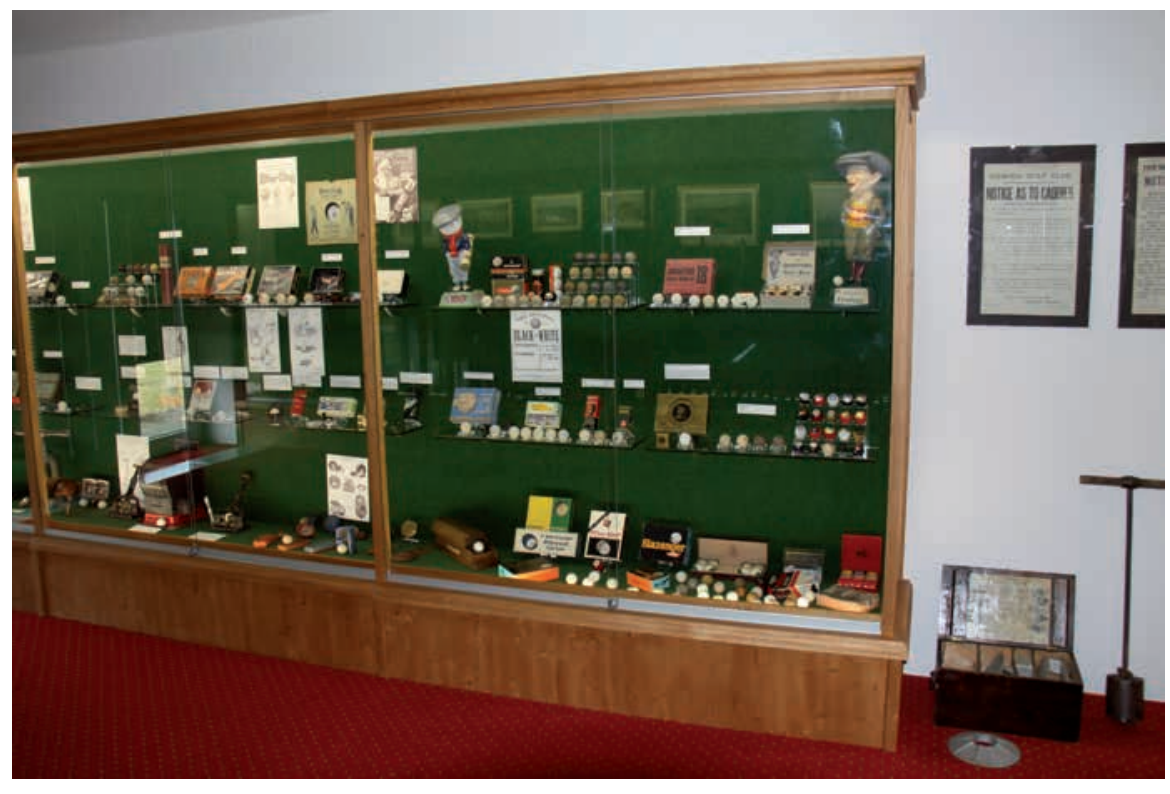

Golf Muzeum Ypsilon, stav k roku 2020

minimálně desítku zápůjček předmětů na sportovní výstavy v různém rozsahu. Rok 2018 s 16 realizovanými zápůjčkami byl extrémem vzhledem ke stému jubileu Československa, nicméně v rámci vývoje od roku 2013 lze i tak zaznamenat z hlediska zápůjček rostoucí trend. Vedle toho jsou sbírkové předměty ze sbírek ODTVS trvale zapůjčeny ve čtyřech výstavních projektech (síň slávy ČSLH, síň slávy FAČR, horolezecká expozice v Muzeu Českého ráje v Turnově, expozice Gustav Frištenský v muzeu v Litovli).

\section{Situace v zemích V4}

Situace v zahraničí se od českých zemí výrazně liší. V řadě zemí fungují instituce zabývající se sportovní a tělovýchovnou problematikou $\mathrm{v}$ různé míre - at’ již na lokální úrovni (historie klubů, případně sportovních odvětví v regionu), na celostátní či přeshraniční úrovni (Síň slávy NHL v Torontu), či instituce zapojené do celosvětových sítí. Nejvýrazněǰsí z těchto expertních sdružení je Sít olympijských muzeí (Olympic Museums Network), do které je z nejbližších sousedů zapojeno varšavské Muzeum sportu i turystyki a bratislavské Slovenské olympijské a športové múzeum. Centrální institucí, která sít olympijských muzeí koordinuje, je Olympijské muzeum ve švýcarském Lausanne. Muzeum bylo založeno v roce 1993 z popudu tehdejšího předsedy Mezinárodního olympijského výboru Juana Antonia Samaranche. Již v roce 1995 získalo titul Evropské muzeum roku. Po rekonstrukci v letech 2011-2013 činí současné expoziční plocha 3000 m². $\mathrm{V}$ rámci muzea funguje i olympijský archiv, knihovna i studijní a informační centrum. Při zakládání olympijského muzea v Lausanne sloužilo tehdejší Oddělení dějin tělesné výchovy a sportu jako vzorová instituce. Řadu let bylo vedení ODTVS v kontaktu s Olympijským muzeem, při personálních změnách a s formální restrukturalizací oddělení v rámci Historického muzea však byly tyto styky přerušeny. Olympijské muzeum v Lausanne představuje vedle muzeí $\mathrm{V}$ rámci $\mathrm{V} 4$ do budoucna klíčového partnera z hlediska sdílení odborných informací z oblasti sportovní, tělovýchovné a zejména olympijské muzeologie. Sít olympijských muzeí (OMN), kterou Olympijské muzeum v Lausanne organizuje, sdružuje v současné době 28 institucí, které spravují sbírky s olympijskou a obecně sportovní tematikou. OMN pořádá každoroční zasedání pro sdílení informací v oboru sportovní a olympijské muzeologie, zároveň poskytuje členským

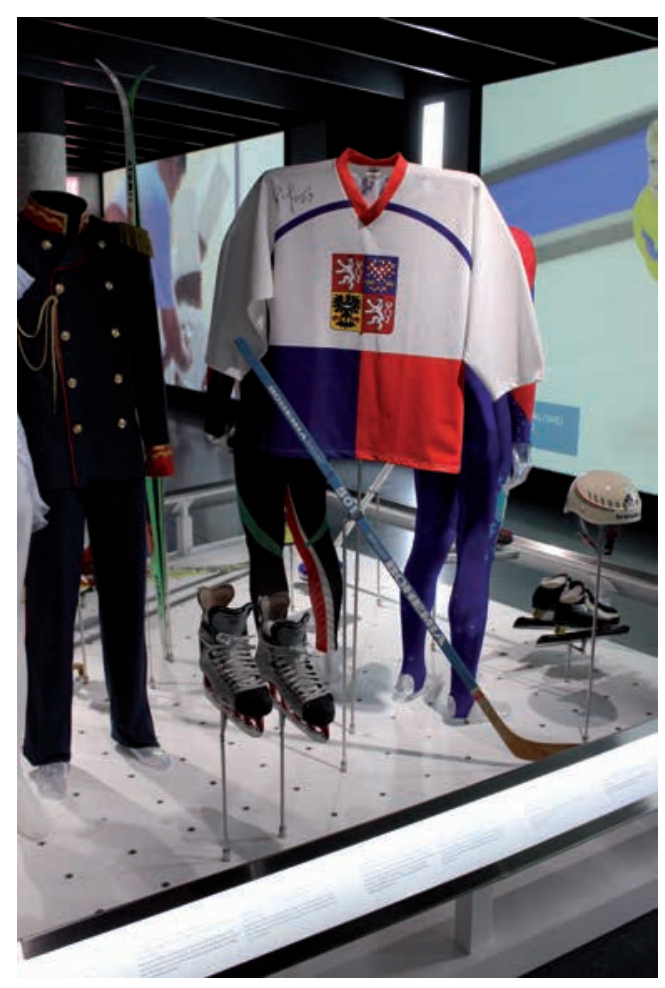

Olympijské muzeum, Lausanne, Švýcarsko, stav k roku 2017 (foto Vlasta Saurová) 
institucím prostor pro výměnu informací či digitalizovaných dat pro vědecké, výstavní či publikační účely. ${ }^{44} \mathrm{Z}$ hlediska srovnání situace okolo sportovního muzejnictví se nabízejí nejbližší instituce v zemích visegrádské čtyřky (V4), tedy na Slovensku, v Polsku a v Mad’arsku. Jedná se o země, které měly relativně podobnou startovní pozici po společenských změnách na přelomu osmdesátých a devadesátých let, stejně tak i sportovní a tělocvičná historie je $\mathrm{v}$ některých směrech srovnatelná. Slovenské olympijské a športové muzeum a polské Muzeum sportu i turystyki jsou členy OMN, mad’arské olympijské muzeum nikoliv.

\section{Slovenské olympijské a športové múzeum}

O založení muzejní instituce, která by mapovala historii sportovního a tělovýchovného dění na Slovensku, se uvažovalo již bezprostředně $v$ poválečném období v souvislosti se založením Státního muzea sportu a tělesné výchovy v Praze. $\mathrm{V}$ rámci tehdejších jednání nebyl bohužel z české strany při zakládání muzea

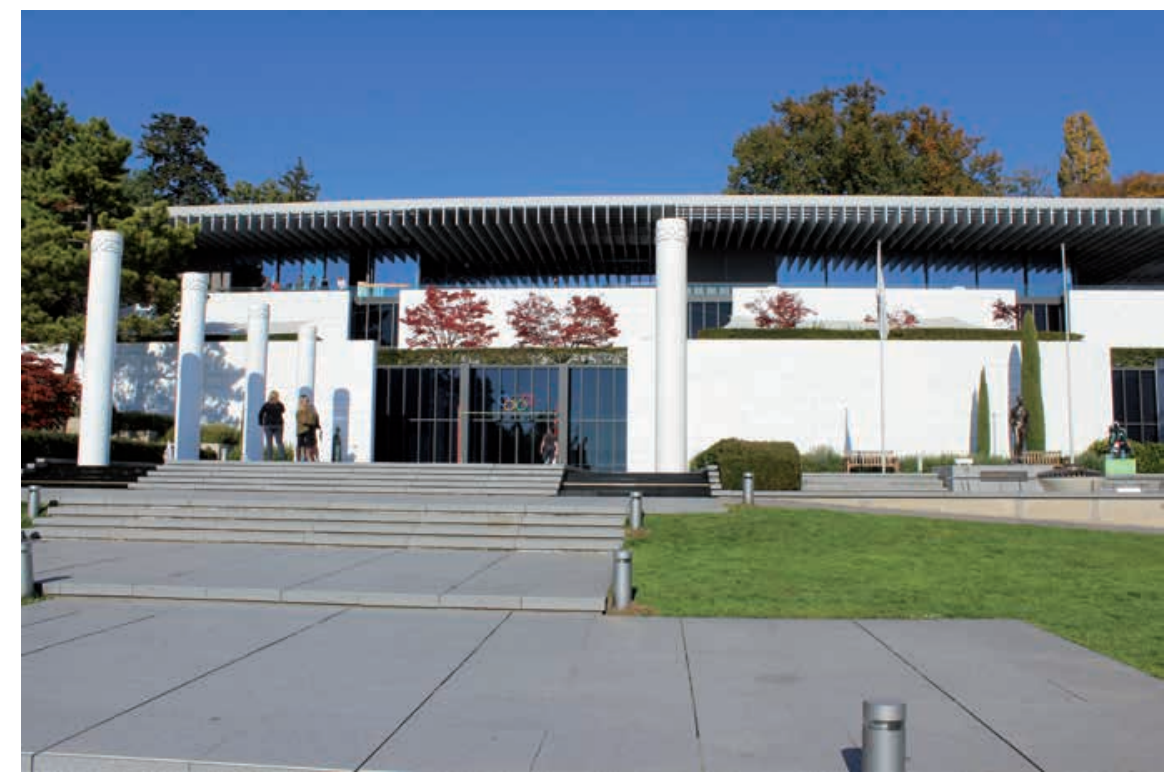

přizván nikdo ze slovenských odborníků věnujících se dějinám sportu a situace tak v tomto směru zůstávala poměrně dlouho napjatá. V ř́jinu roku 1985 bylo muzeum ustanoveno zřizovací listinou předsednictva Ústředního výboru Československého svazu tělesné výchovy pod názvem Múzeum telesnej kultury. K první evidenci sbírkových předmětů došlo v roce 1987. ${ }^{45}$ Od roku 2015 se muzeum stalo organizační složkou Slovenského olympijského výboru a změnilo svůj název na Slovenské olympijské a športové muzeum. V současné době za chodem muzea stojí tři odborní pracovníci, včetně

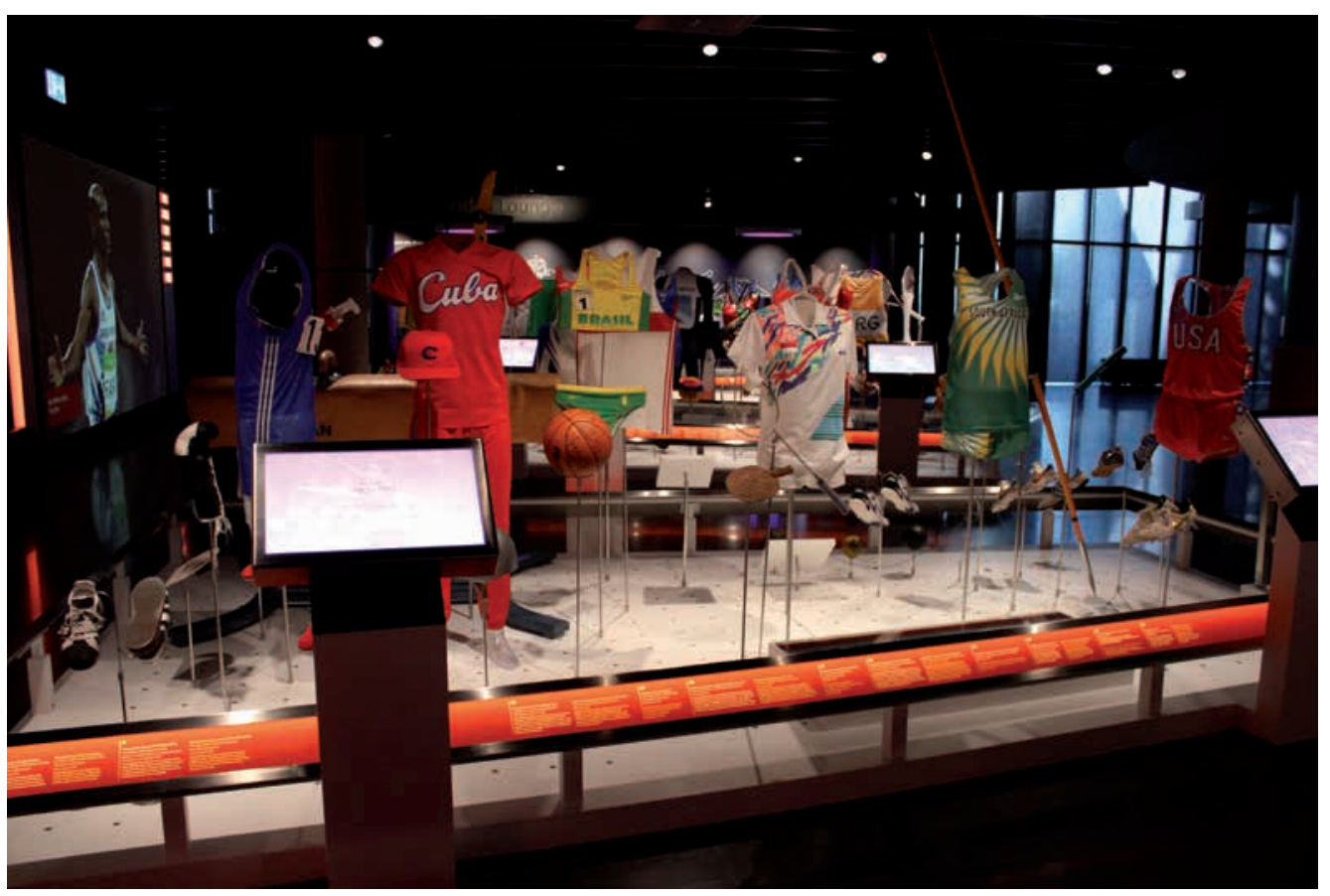

Olympijské muzeum, Lausanne, Švýcarsko, stav k roku 2017 (foto Vlasta Saurová)

44 Srov. https://www.olympic.org/museum/collaborate/ olympic-museums-network, cit. k 20. 8. 2020.

45 Srov. ŠTURSOVÁ, Květoslava. Nástin dějin československého tělovýchovného a sportovního muzejnictví 4. Muzejní a vlastivědná práce, 1991 , roč. 29 , č. 2 , s. 65-73. 


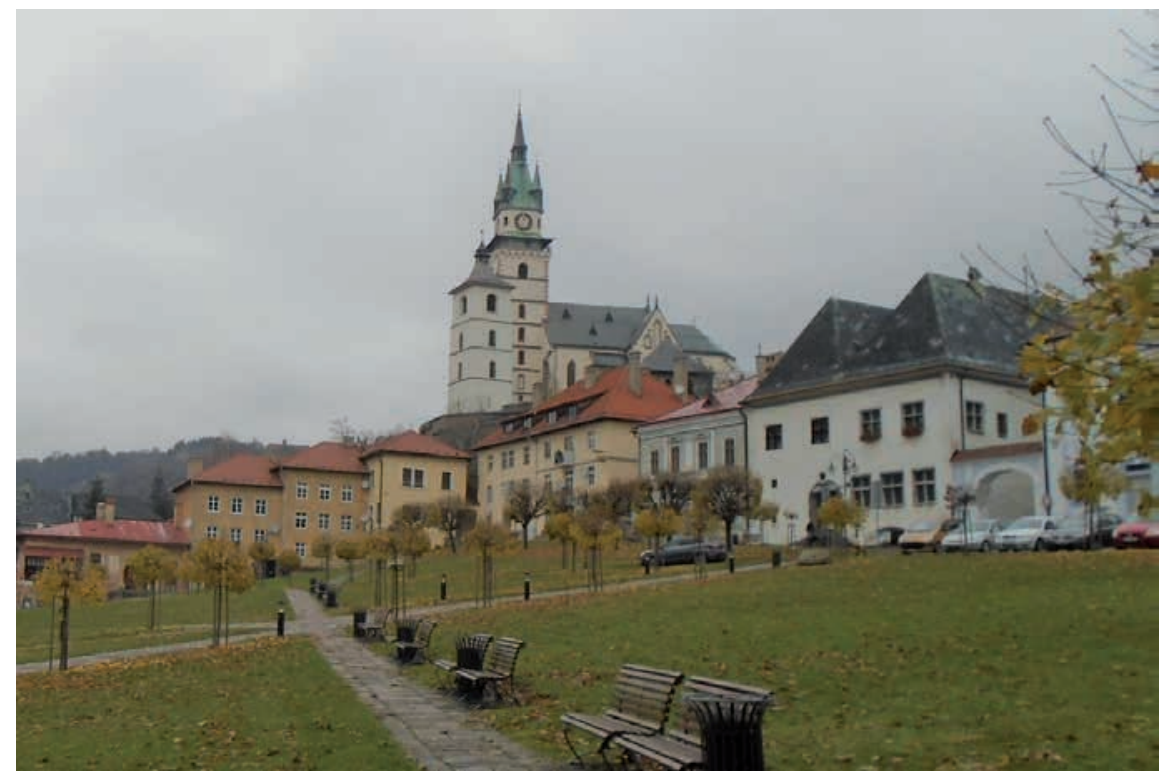

Stálá expozice SOŠM Lyžiarské múzeum, Kremnica, stav k roku 2016

46 Srov. https://www.olympic. sk/muzeum; https://www.olympic.sk/publikacielknihy-brozury, cit. k 20. 8. 2020.

47 Ústní sdělení, Viliam Karácsony, 24. 10. 2019. ředitelky Zdeny Letenayové, a dvě pracovnice spravující stálou expozici lyžování. Muzeum každoročně organizuje několik výstavních projektů, v současnosti připravuje novou stálou expozici věnovanou slovenskému olympismu. SOŠM vedle toho spravuje i stálou expozici Lyžiarské múzeum v Kremnici věnovanou vývoji tohoto sportovního odvětví na Slovensku. Zároveň pracovníci muzea publikují každoročně několik odborných brožur a monografií. ${ }^{46}$ Muzeum dělí své sbírky na trojrozměrnou sbírku, fotoarchiv a knihovnu. Trojrozměrná sbírka v současnosti obsahuje 27000 zapsaných sbírkových předmětů, fotoarchiv 26457 fotografií, archiv obsahuje pomocné materiály ke sbírkovým předmětům. V současné době se diskutuje o propojení sbírkových databází s Olympijským muzeem v Lausanne. ${ }^{47}$

\section{Muzeum sportu i turystyki}

Jedním z nejstarších muzeí věnovaných oboru je polské Muzeum sportu a turystyki ve Varšavě. Muzeum bylo založeno $\mathrm{v}$ roce 1952 a ve srovnání s historií sportovní muzeologie $\mathrm{v}$ českých zemích lze $\mathrm{v}$ rámci vývoje této instituce sledovat spíše obrácený trend, kdy se vedle nárůstu sbírek a zvětšování expozičních prostorů úměrně navyšuje i počet odborných pracovníků. V roce 1952 při svém vzniku tak mělo muzeum dva pracovníky, v roce 196833 pracovníků, v devadesátých letech se stav poněkud snížil, ale v roce 2002 to bylo stále 17 pracovníků. Stálá expozice muzea se od roku 2006 nachází ve varšavském Olympijském centru. Rozkládá se na ploše $1000 \mathrm{~m}^{2}$ a prezentuje veřejnosti na 3000 sbírkových předmětů mapujících nejen dějiny světového a polského olympijského hnutí, ale také polské tělocvičné jednoty Sokol, bruslení, hokeje, úpolových sportů, míčových sportů, vodních sportů, motoristických sportů, lehké atletiky a dalších. V současné době sbírky obsahují 50000 trojrozměrných sbírkových předmětů, 55000 fotografií,

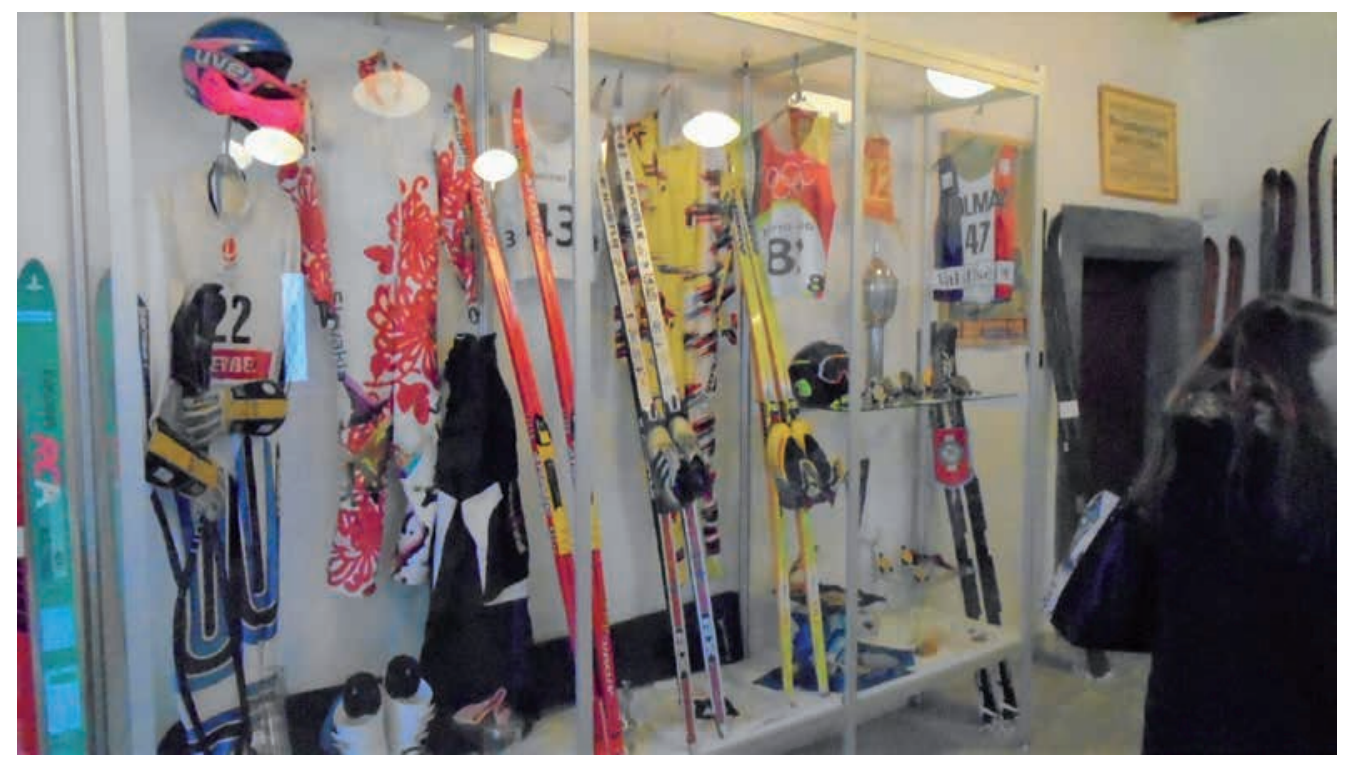

Stálá expozice SOŠM Lyžiarské múzeum, Kremnica, stav k roku 2016 
16000 publikací a kolem 2000 dokumentů a archiválií. ${ }^{48}$ Pod Muzeum sportu i turystyki spadalo do roku 1974 i Muzeum Sportu i Turystyki Regionu Karkonoszy v Karpaczi, které však bylo od 2003 osamostatněno a přeřazeno pod jiné organizace polské samosprávy.

\section{Madarské olympijské a sportovní muzeum (Magyar olympiai és sportmúzeum)}

Muzeum bylo založeno v roce 1963 jako celonárodní instituce mapující dějiny mad’arského sportu, olympismu a fyzické kultury obecně. Od roku 2012 funguje jako součást Národních sportovních center. Sbírkovou činnost zaměřuje zejména na doklady historického vývoje sportů a olympismu v Mad'arsku. Z hlediska sbírkových předmětů obsahují sbírky přes 800000 položek, nicméně tento počet zahrnuje jak trojrozměrné sbírkové předměty, tak fotografické a archivní materiály. Za poslední čtvrtstoletí organizovalo muzeum na 200 výstav se sportovní tematikou, které se věnovaly jak jednotlivým sportovním odvětvím (atletika, zápase, veslování, cyklistika,

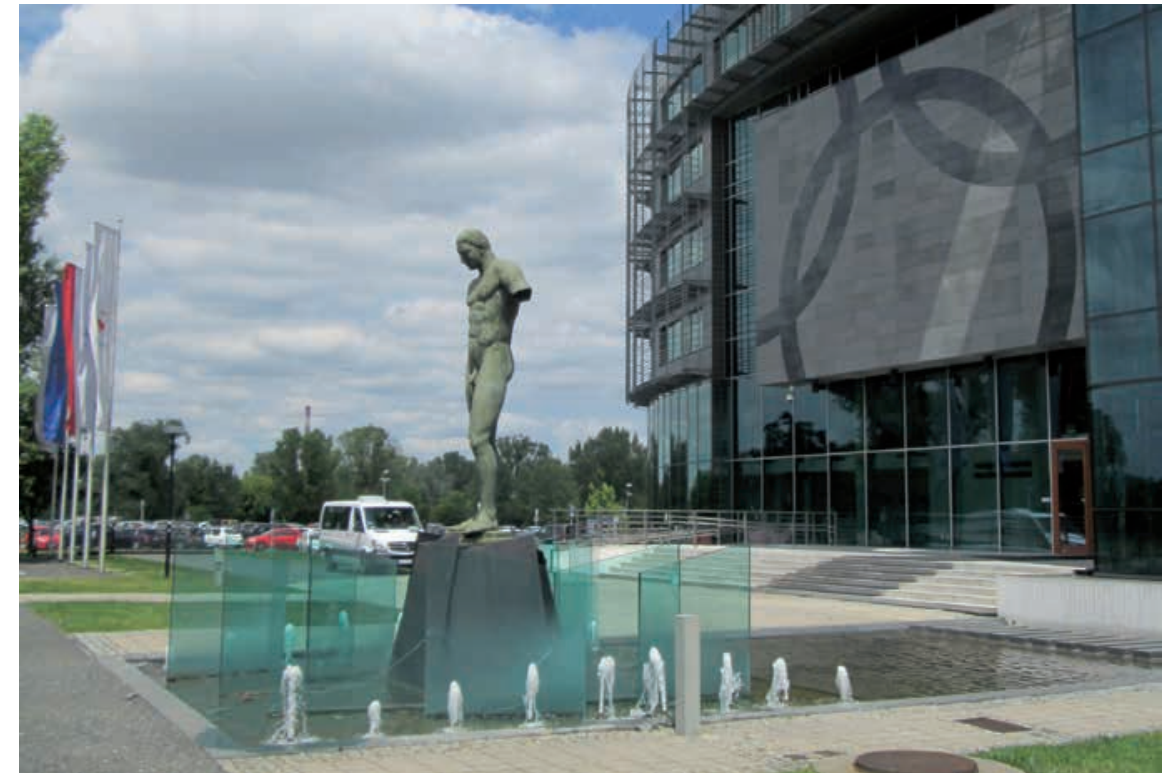

fotbal, turistika), tak historii skautského hnutí, tělesné výchovy, ženskému sportu, dílčím olympijským hrám aj. Muzeum zároveň pořádalo několik putovních výstav k mad'arskému sportu jak v zahraničí (Lausanne, Sydney, Paříž), tak na území Mad’arska. V současnosti muzeum spravuje čtyři stálé expozice - ve výstavní síni Sport Agóra v budapešt'ské Papp László Sportaréna, olympijskou expozici v návštěvnickém centru nově rekonstruovaného fotbalového stadionu Puskás Aréna, expozici vodních sportů a turistiky. ${ }^{49}$

Situace v zemích V4 je tak z hlediska institucionálního ukotvení a stálé prezentace
Muzeum sportu i turystyki, Varšava, stav $k$ roku 2015

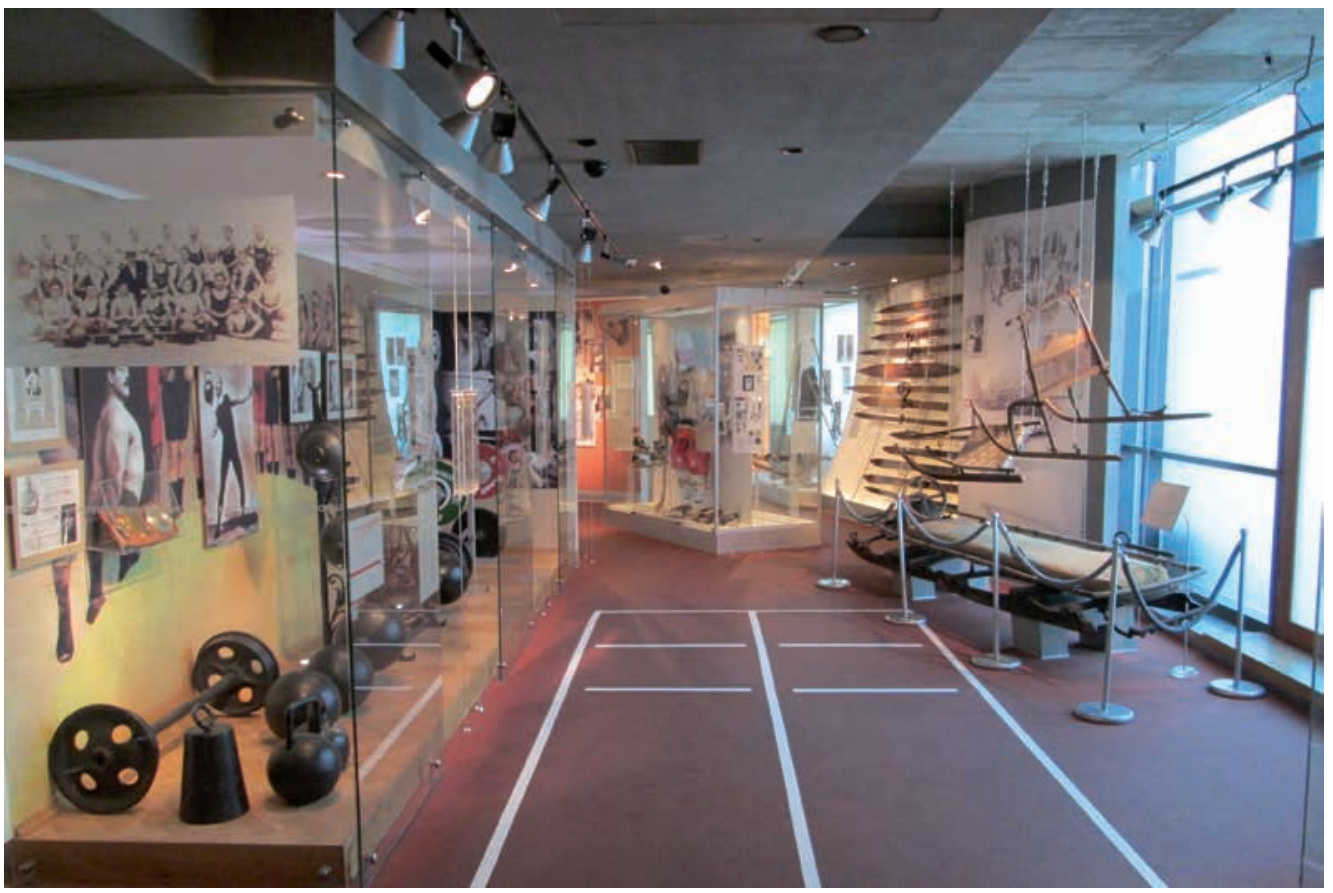

Muzeum sportu i turystyki, Varšava, stav k roku 2015
48 Srov. GRYS, Ivona (ed.). The History of Polish Sports and the Olympic Movement. A Permanent Exhibition at the Museum of Sports and Tourism in Warsaw. Varšava: Estrella, 2010, 76 s., vedle toho i https://www.muzeumsportu. waw.pl/muzeum/o-muzeum/ historia, cit k 14. 8. 2020. 49 Srov. http://www.sportmuzeum.hul, cit. k 14. 8. 2020. 


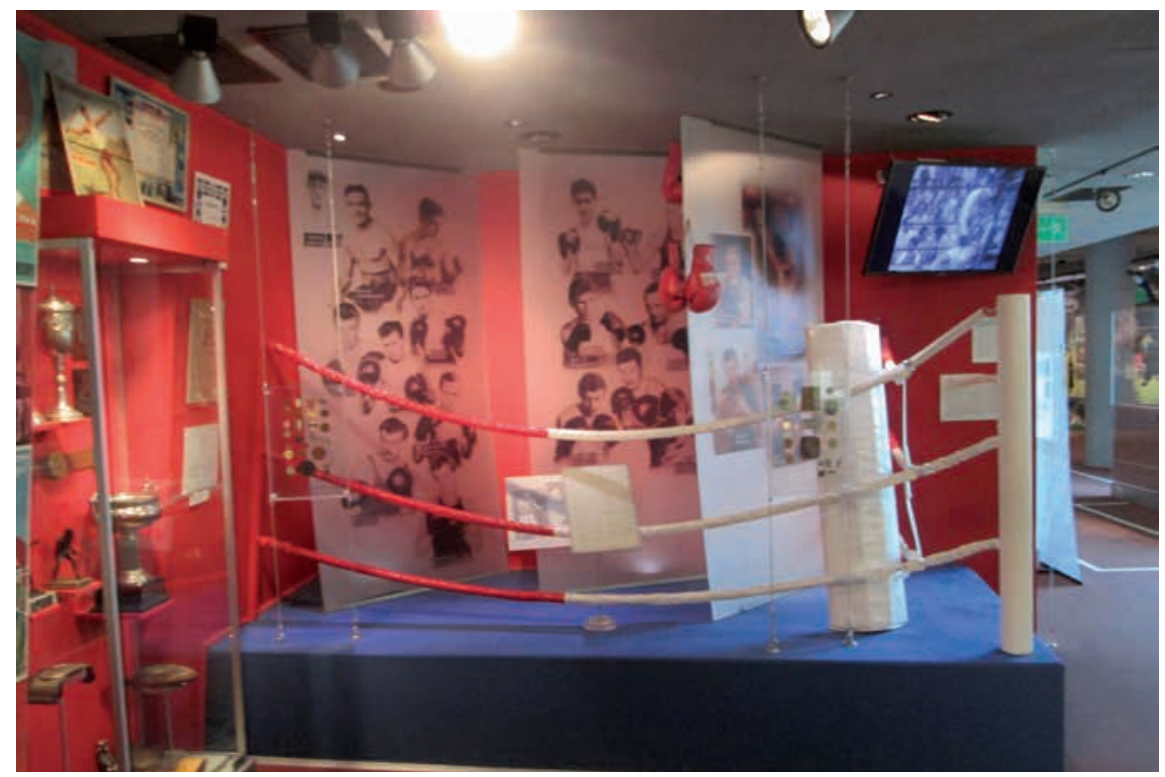

Muzeum sportu i turystyki, Varšava, stav k roku 2015

sportovních témat poměrně stabilní, bez výrazných diskontinuit. Zmíněné muzejní instituce spravují minimálně jednu stálou expozici, která jim umožňuje realizaci výstavních projektů i komunikaci s veřejností. V případě všech zmíněných muzejních institucí toto ukotvení také ulehčuje komunikaci s pamětníky a akviziční činnost.

\section{Závěr}

Současná situace kolem tělovýchovného a sportovního muzejnictví v ČR je ve stadiu transformace, kdy absenci stálé expozice zaměřené na dějiny české tělesné výchovy, sportu a olympismu nahrazují lokální muzea či dílčí soukromé expozice. $\mathrm{Z}$ tohoto hlediska je patrné, že řada regionálních a soukromých expozic vzniká v posledním desetiletí, kdy je v oblasti výstav věnovaných sportu a tělesné výchově patrná absence stálých výstavních prostor určených pro prezentaci historických témat vztažených $\mathrm{k}$ dějinám tělesné výchovy, sportu a olympismu na našem území. K tomu jistě zapůsobila i personální a organizační diskontinuita $\mathrm{v}$ rámci vývoje Oddělení dějin tělesné výchovy a sportu, která v podstatě anulovala jak dosavadní začlenění do širších odborných struktur, tak i povědomí odborné i laické veřejnosti ohledně historicky cenných sportovních a tělovýchovných sbírek v Národním muzeu.

V okamžiku, kdy v historicky krátké době nevznikne prostor, ve kterém by mohlo Oddělení dějin tělesné výchovy a sportu prezentovat svoje bohaté sbírky a svoji činnost, bude tento proces zřejmě nevratný. Dějiny tělesné výchovy a sportu představují poměrně širokou platformu pro komunikaci s veřejností, stejně tak skrývají značný návštěvnický potenciál, a to napříč společností. V zahraničí existuje řada muzejních institucí, které se tomuto oboru lidské činnosti věnují, jsou začleněny do širších odborných struktur a vykazují výrazně lepší výsledky jak na poli odborném, tak ekonomickém. Samostatná expozice by umožňovala prohloubit komunikaci s laickou i odbornou veřejností, znamenala by také nejen odborný, ale i ekonomický přínos. $\mathrm{V}$ případě, kdy stálá expozice nevznikne, lze předpokládat, že se sbírky stanou pouze jakýmsi fundusem pro výstavy jiných institucí a pracovníci oddělení se budou věnovat pouze servisním úkonům. Perspektivy jsou tak $v$ tomto směru zatím poměrně neradostné a současný stav rozhodně není optimální. Zatímco objem sbírek i další činnosti, stejně jako doprovodná administrativa rostou, počet odborných pracovníků kontinuálně klesá. Při absenci dokumentátorů musí zároveň kurátoři vykonávat i řadu doprovodných činností v oblasti péče o sbírky. K optimalizaci akviziční i odborné činnosti by vedlo zdvojení kurátorských pozic na osm odborných pracovníků, nouzovým řešením by bylo alespoň doplnění současného personálního stavu o dvě kurátorská místa. Je zřejmé, že v současné situaci resortu kultury je úvaha o navýšení počtu pracovních míst v podstatě nereálná. V nedávné době se také přiliš neosvědčilo doplňování oddělení o pracovníky v režimu dohody o pracovní činnosti, protože tento systém nepřináší potřebnou stabilitu pracovního týmu.

Přestože současná doba příliš nepřeje optimistickým vizím, je zde namístě nastínit scénář, který by byl pro budoucnost prezentace sportovní a olympijské historie v muzeu ideální. Při jeho nástinu je potřeba vycházet ze skutečnosti, že v zahraničí patří sportovní a olympijská muzea k úspěšným a navštěvovaným institucím. Zájem široké veřejnosti o sport a olympismus jde napřič společenskými skupinami, at již na ně nazíráme $\mathrm{z}$ pohledu materiálního, či světonázorového. Variabilita 
a rozsah samotné oblasti sportu, tělesné výchovy a olympismu, která v moderních dějinách prošla značnou proměnou a mnohdy dynamickým rozvojem, umožňuje prezentovat i zkoumat celou řadu témat a společenských fenoménů. $\mathrm{V}$ př́padě stálé prezentační činnosti zahraničních specializovaných institucí se projevují ve srovnání se současnou situací v ČR jednoznačná pozitiva jak $\mathrm{v}$ oblasti komunikace $\mathrm{s}$ veřejností, tak $\mathrm{v}$ oblasti expoziční, akviziční, výzkumné a publikační. $Z$ pohledu uchování národního kulturního dědictví i v této oblasti je tak vybudování centrální specializované stálé expozice v zájmu celé české veřejnosti.

Možnosti realizace centrální sportovní expozice v ČR se v zásadě nabízejí dvě. Jednou je její zř́zení $v$ rámci Národního muzea, druhou pak mimo něj, tedy vznik samostatného muzea českého sportu. Návrhů na vybudování stálé expozice $\mathrm{v}$ rámci Národního muzea byla v nedávné minulosti celá řada. Realizace narazila vesměs na absenci vhodných prostor, které by mohly být pro stálou expozici vyčleněny a zajištěny bez větších finančních nákladů v podobě komerčního pronájmu, či dokonce vybudování nového objektu. Vysoký nájem prostorů byl ostatně hlavní př́činou ukončení činnosti původní stálé expozice $\mathrm{v}$ Tyršově domě. $\mathrm{V}$ souvislosti s hledáním vhodného objektu proběhlo i několik neúspěšných jednání s institucemi z oblastí spojených se sportem a olympismem. $\mathrm{V}$ současné době jedna $\mathrm{z}$ variant realizace expozice závisí na výsledku jednání ministerstva kultury s pražským magistrátem.

Myšlenka vyčlenění sbírky a vzniku samostatné muzejní instituce zaměřené na dějiny českého sportu, tělesné výchovy a olympismu není nová, tato varianta byla navrhována mimo jiné i bezprostředně po společenských změnách $\mathrm{v}$ roce 1989. Po pưlstoletí fungování v rámci Národního muzea a postupné integraci do jeho struktur by vyčlenění znamenalo především vyřešení otázek zázemí, administrativního převodu sbírek evidovaných $\mathrm{v}$ centrální evidenci, jejich uložení a soustavné péče o ně. $S$ touto problematikou úzce souvisí i otázka personálního zabezpečení a finančního zajištění celého projektu. A to výčet prozatím zahrnuje pouze otázku správy sbírek, nikoliv problematiku vlastního zajištění stálé expozice, kde by náklady dále vzrostly. $\mathrm{V}$ návaznosti na tyto problémy se úvahy o vyčlenění sbírky do samostatné instituce bez výrazného finančního zajištění pohybují pouze $\mathrm{v}$ teoretické rovině. Sportovní svazy i občanské spolky vesměs sledují své partikulární zájmy. Teoreticky by tedy byla z hlediska zř́zení stálé expozice ideální forma meziresortní spolupráce mezi ministerstvy kultury a školství, mládeže a tělovýchovy, př́padně Národní sportovní agenturou.

$\mathrm{V}$ rovině teorie se pohybuje i vize, jaké by mělo být ideální personální obsazení či materiální zázemí instituce, která by spravovala sbírky i stálou expozici dějin sportu, tělesné výchovy a olympismu $\mathrm{v}$ českých zemích. Vyjdeme-li ze skutečnosti, že připravovaná stálá expozice SOŠM na Slovensku má mít rozsah do $400 \mathrm{~m}^{2}$ a expozice varšavského Muzea sportu i turystyki se rozkládá na $1000 \mathrm{~m}^{2}$, pak optimální plocha pro stálou expozici českého sportu, tělovýchovy a olympismu by měla mít minimální rozsah $800 \mathrm{~m}^{2}$. Z hlediska personálního by pak byl ideální počet osmi pracovních míst na kombinované pozici pracovník ve vědě a výzkumu / kurátor sbírkového fondu, minimálně jedno pracovní místo dokumentátora sbírkového fondu a jedno pracovní místo správce depozitáře. Vedle toho i personální zajištění ostrahy expozice.

Vrátíme-li se od teoretických vizí k realitě, je bezprostředním úkolem současného Oddělení dějin tělesné výchovy a sportu pokračovat $\mathrm{v}$ dosavadní akviziční a odborné činnosti a snažit se o navázání co nejširší spolupráce se specializovanými institucemi a odborníky nejen v ČR, ale také v zahraničí. Jako jedna z možností do budoucna se jeví uspořádání obdobné specializované mezinárodní akce, jakou byla konference Šport a olympijské hnutie $v$ múzejnej dokumentácii, kterou zorganizovalo v roce 2018 Slovenské olympijské a športové múzeum. Dlouhodobým cílem je pak př́íprava a realizace vstupu do Sítě 
olympijských muzeí (Olympic Museums Network), která představuje celosvětové expertní sdružení v oblasti olympijského, sportovního a tělovýchovného muzejnictví. Umožnilo by to uchování povědomí o sbírce Oddělení dějin tělesné výchovy a sportu alespoň v zahraničí.

\section{Literatura}

GRYS, Ivona (ed.) The History of Polish Sports and the Olympic Movement. A Permanent Exhibition at the Museum of Sports and Tourism in Warsaw. Varšava: Estrella, 2010, 76 s.

HAVRÁNKOVÁ, Hana et al. Český olympismus: 100 let. Praha: Olympia, 1999, $160 \mathrm{~s}$.

JAKUBCOVÁ, Kristina. Sport a olympijské hnutí v zemích Visegrádu: jejich vývoj a jejich transformace v postkomunistické ére. Praha: Karolinum, 2012, 206 s.

KOLÁ̌̌r, František a kol. Kdo byl kdo. Naši olympionici. Praha: Libri, 1999, 424 s.

LOMÍČEK, Jan. Možnosti a limity dokumentace současnosti českého sportu, tělesné výchovy a olympismu. Acta Musei Nationalis Pragae - Historia, 2017, roč. 71, ̌̌. 3-4, s. 5-10.

LOMÍČEK, Jan et al. Sport za velké vál$k y=$ Sport during the great war. Praha: Národní muzeum, 2017, 29 s.

RÁMIŠOVÁ, Šárka. S hrdostí nošený: sokolský kroj, úbor a scénický kostým. Praha: Národní muzeum, 2018, 327 s.

RÁMIŠOVÁ, Šárka a SWIERCZEKOVÁ, Lucie. Móda pod olympijskými kruhy: nástupové oblečení od Athén až po Rio. Praha: Mladá fronta, 2016, 158 s.

SCHŮTOVÁ, Jitka. Knihovna sbírky tělesné výchovy a sportu ... a co jí predcházelo. Praha: Národní muzeum, 2015, 126 s.

SCHŮTOVÁ, Jitka. Manželka, matka, tchyně: dochované památky a korespondence Kateřiny Fügnerové. Praha: Národní muzeum, 2018, $463 \mathrm{~s}$.

SCHŮTOVÁ, Jitka, HAVRÁNKOVÁ, Hana, SAUROVÁ, Vlasta. Olympionika v trojrozměrné Sbírce tělesné výchovy a sportu Národního muzea. Praha: Národní muzeum, 2012, 152 s.

SCHŮTOVÁ, Jitka, SAUROVÁ, Vlasta, HAVRÁNKOVÁ, Hana. Signované kresby a obrazy Oddělení dějin tělesné výchovy a sportu Národního muzea. Praha: Národní muzeum, 2008, 188 s.

SCHŮTOVÁ, Jitka, HAVRÁNKOVÁ, Hana, SAUROVÁ, Vlasta. Signované plastiky a sportovní trofeje: sbírka tělesné výchovy a sportu Národního muzea. Praha: Národní muzeum, 2010, 282 s. SOUČKOVÁ, Tatána, RÁMIŠOVÁ, Šárka. Pochod Praha - Prčice: padesát ročníků 1966-2015. Praha: KČT PrahaPrčice, 2015, 205 s.

SWIERCZEKOVÁ, Lucie. Prüvodce po archioních fondech a sbirkách Oddělení dějin tělesné výchovy a sportu Národního muzea. Praha: Národní muzeum, 2007, 88 s.

ŠTURSOVÁ, Květoslava. Tyršovo muzeum tělesné výchovy a sportu 1953-2003. Praha: Národní muzeum, 2003, 67 s.

ŠTURSOVÁ, Květoslava. Nástin dějin československého tělovýchovného a sportovního muzejnictví 1, In Muzejní a vlastivědná práce, 1990, roč. 28, č. 4, s. $136-154$.

ŠTURSOVÁ, Květoslava. Nástin dějin československého tělovýchovného a sportovního muzejnictví 2, In Muzejní a vlastivědná práce, 1990, roč. 28 , č. 4 , s. 193-199.

ŠTURSOVÁ, Květoslava. Nástin dějin československého tělovýchovného a sportovního muzejnictví 3. Muzejní a vlastivědná práce, 1991, roč. 29, č. 1, s. 1-12.

ŠTURSOVÁ, Květoslava. Nástin dějin československého tělovýchovného a sportovního muzejnictví 4. Muzejní a vlastivědná práce, 1991, roč. 29, č. 2, s. 65-73.

ŠVÁCHA, Rostislav et al. StArt: sport jako symbol ve výtvarném umění. Vydání první. V Řevnicích: Arbor vitae ve spolupráci s Českým olympijským výborem a Ústavem dějin umění AV ČR, v.v.i., 2016, 315 s. 